\title{
DISKUSSIE
}

\section{MAG DIE KERK SKEUR?}

\section{Tradisioneel Gereformeerde standpunt}

\subsection{Die na-reformatoriese standpunt}

Die tradisioneel gereformeerde standpunt is dat kerkskeuring soms plig kan wees, dat deformasie in 'n bepaalde kerkverband so wyd om hom heen kan gryp dat lidmate van Godsweë geroep word om daardie kerkverband te verlaat en 'n nuwe te vorm. „Die waarheid moet bo die eenheid verkies word, want wat baat ' $n$ eenheid waarin die onwaarheid vrye spel het?"

Hierdie visie tref ons aan in nagenoeg alle gereformeerde dog. matiekhandboeke. „Als eene kerk in hare ambten en bedieningen toont, zichzelve en hare ordinantiën meer autoriteit toe te kennen dan den woorde Gods en zich duidelijk als eene valsche kerk openbaart", so betoog Bavinck, ,dan hebben de geloovigen het heilige officie en den schuldigen plicht, om zich af te scheiden en wederom kerkelijk te gaan leven naar des Heeren woord".'2 Praamsma aanvaar dit as 'n vanselfsprekendheid: „Dat er een recht van Afscheiding is, of beter gezegd een recht tot verbreking van de banden met een bepaald kerkelijk instituut, is een waarheid, die voor alle zonen der Reformatie geen nader betoog behoeft". ${ }^{3}$ En in die jongste gereformeerde dogmatiek oordeel $K$. Dijk ook dat, nadat alle interne reformatoriese pogings misluk het, dit gebode kan wees „om in de weg van Afscheiding of Doleantie het verband met de ,regering der kerk" te breken, en in deze weg tot reformatie te komen".

\subsection{Die Gereformeerde Kerk in Suid-Afrika}

Hierdie visie word ook gedeel deur die Gereformeerde Kerk in Suid-Afrika. In 1967 word daar besluit dat as voorlopige riglyn vir die ekumeniese optrede van hierdie kerk (beter: kerkverband of kerkgroep) onder andere sal dien dat ,die eenheid met die Here van die kerk kan onder bepaalde omstandighede die verbreking van 'n valse eenheid in die kerk 'n eis maak". ${ }^{5}$ Hierdie ,voorlopige rig. lyn" van 1967 het in 1970 'n definitiewe geword.6

Suid-Afrikaanse gereformeerde teoloë is ook hierdie mening toegedaan. ${ }^{7}$

\subsection{Die visie van die Reformatore}

Dit is 'n ope vraag of hierdie visie van ,kerkskeuring-is-somsplig" ook by die reformatore, veral by Luther en Calvyn, te vind is. Ten opsigte van Luther oordeel Berkhof „dat dit allerminst die bedoeling van Luther en de zijnen is geweest (om de kerk te skeur). Zij wilden de oude kerk tot de gehoorzaamheid aan de Heilige Schrift terugvoeren, niet een nieuwe kerk stichten. Buiten hun wil is het daartoe gekomen". ${ }^{8}$ Die standpunt van Calvyn is moeilik onder een 
noemer te bring en dra die spore van 'n sekere dialektiek. So kan hy byvoorbeeld enersyds beweer dat elke vergadering en die hele liggaam van die pousdom die wettige gedaante van 'n kerk mis, terwyl hy andersyds toegee dat daar by Rome „,nog kerke" is. ${ }^{9}$ Tereg kan Nauta daarom die aandag vestig op Calvyn se afkeuring van 'n skeuring, ${ }^{1}$ hoewel dit tog uit die volgende woorde van Calvyn skyn asof hy die kerk voortdurend voor 'n ,oop situasie" geplaas sien: „Wat mij betreft, ik zal mij nooit laten overhalen de auteur van een schisma te worden, tot ik eindelijk zou bemerken dat de kerk ten volle van de dienst Gods en de verkondiging van het Woord is afgevallen"." Uit die groot studie van Polman oor die Nederlandse Geloofsbelydenis (veral artikels 27-29) blyk duidelik dat die standpunte van die reformatore allesbehalwe in 'n simplistiese swart-witskema ingeforseer kan word. ${ }^{12}$

Gesien, enersyds, die tragies verskeurde kerklike situasie en die voortdurende dreigende skeuringe, en, andersyds, die steeds groeiende ekumeniese strewe (wat helaas op sy beurt dreig om in ' $n$ verskeurende faktor om te swaai) en die hernude belangstelling vir die kerk met die oog op die koms van die koninkryk van God, is dit gewens, noodsaaklik en selfs onmisbaar om aan hierdie lang verwaarloosde onderdeel van die ekklesiologie aandag te gee.13 Hierdie poging wil geen ,indringende aandag" wees nie, slegs 'n stimulans daartoe. Daarvoor kies ons die metode van vraagstelling met voorlopige antwoorde.

\section{Enkele noodsaaklike vrae}

Uit die volgende vrae behoort - hopelik - minstens te blyk dat die vanselfsprekendheid waarmee die saak van kerkskeuring bejeën word, nouliks meer te handhaaf is.

\subsection{Christologiese vraag}

Die vraag kan met reg gestel word of die Christologie nie met 'n kerkskeuring op sy kop geplaas word nie, en dan sowel ten opsigte van wat Jesus Christus gedoen as wat Hy beloof het. Word sy heilryke beloftewoord, naamlik dat Hy met sy Kerk sal wees ,al die dae tot aan die voleinding van die wêreld" (Matt. $28: 20$ ), nie deur die verskillende kerkskeuringe dusdanig gerelativeer dat alleen maar 'n holle klank daarvan oorgebly het nie? Of sou hierdie garansie implisiet vanuit die mag van die sonde sy $\mathrm{krag}$ ontneem kon word ? $^{14}$ En is dit nog moontlik vir die talle - afgekampte - kuddes om hulle visie op die ,een Herder", wat sy lewe vir hulle afgelê het, te behou? (Joh. $10: 16$ ). Of impliseer die meer-as-een-kudde dalk 'n meerderheid van herders? En watter interpretasie gee ons van die hoëpriesterlike gebed om eenheid, ,opdat (doelsin!) die wêreld kan glo dat U My gestuur het"? (Joh. 17:21). Of sal ons dit afswak met die teorie oor die „onsigbare kerk", of met die teorie van die „pluriformiteit”, of met die absolutisme van net één ware kerk. of met ' $n$ fatalistiese hamartologie, of in eskatologiese verwagting? ${ }^{15}$ 
Of sal ons die bewoënheid van hierdie gebed relativeer met die rasionalistiese argument „dat Gods Woord ons wel openbaart, dat er éen kerk moet zijn, maar niet dat er ook één kerk zal zijn". ${ }^{16}$ En wat maak ons met die Pauliniese beeldspraak van die kerk as die liggaam van Christus? (vgl. Rom. 12, 1 Kor. 6 \& 12, Ef. 4). Kan die Hoof meer as een liggaam hẽ? (vgl. Ef. $4: 4$ ). Indien ons die reformatoriese kritiek op Rome aanvaar, naamlik dat die pous nie die aardse hoof van die kerk kan wees naas (of saam met) Christus as die hemelse Hoof nie, omdat 'n liggaam met twee hoofde 'n gedrog is, moet ons nie dan ook die omgekeerde aanvaar nie, naamlik dat 'n Hoof met twee of meer liggame ook 'n onding is? ${ }^{17}$

En wat anders as die Christelike doop - en die geloof - is die konstitutiewe faktor by kerkverband, aangesien die dopeling hiermee ingelyf word in die liggaam van Christus en so deel word van sy Kerk?

Het Christus nie sy eie mense - die Ou-Testamentiese volk van God - liefgehad "tot die einde toe" nie (Joh. $13: 1$ ), en behoort elke Christen - as návolger - nie ook dieselfde te doen met die Nieu-Testamentiese volk van God nie?

\subsection{Pneumatologiese vraag}

Die vraag kan ook gestel word of die Pneumatologie, in sy verhouding tot die ekklesiologie, nie in gedrang kom nie. Hoedanig funksioneer die ,ander Trooster", die Heilige Gees, wat aan die Kerk gegee is om by die kerk te bly "tot in ewigheid" (Joh. $14: 16$ ), met die doel om die kerk ,in die hele waarheid te lei" (Joh. $16: 13$; vgl. 1 Joh. $5: 6$ ), wanneer die een Kerk uiteenval in 'n aantal geisoleerde kerkgroepe? „Zou de wondermooi ineengevoegde tempel van de Heilige Geest ooit uiteengegooid kunnen worden in een veelheid van tempeltjes, kapelletjes en allerlei heiligdommen, waarin men elkaar wederzijds het licht in de ogen niet gunt, elkaar de gelovigen aftroggelt en de geloofwaardigheid van de ene en enige God en Vader zelf in discrediet brengt?"18 Is ons as reformatoriese Christene wel konsekwent - en eerlik - wanneer ons alle onfeilbaarheid en outomatisme, soos by Rome, afwys (God kan 'n gemeente uit sy mond spuug, Openb. $3: 16$ ), maar dit terselfdertyd by die agterdeur inlaat met die luidkeelse proklamasie: Die Gees verlaat "my" kerk of kerkvergadering nooit!? En inderdaad, want die inwoning en leiding van die Gees is geen irreële of fiktiewe garansie nie. ${ }^{19}$

\subsection{Ekklesiologiese vraag}

Ook vanuit die ekklesiologie self spring die vrae na vore. Kan daar sprake wees van meer as één kerk, nie in die sin van 'n gesonde pluriformiteit (verskeidenheid) nie, maar in die sin van 'n - sondige - pluraliteit (verskeurdheid)? Kan die relasie tussen Kerk en God ooit anders wees as „een liggaam en een Gees ..., een Here, een geloof, een doop, een God en Vader..."? (Ef. 4:4-6). 
Is dit moontlik vir die één kerk om uiteen te val in 'n „Paulus-kerk”, 'n „Apollos-kerk”, 'n „Petrus-kerk” én 'n ,Christus-kerk”? Of 'n ,Jan-van-Riebeeck-kerk”, 'n „Dirk-van-der-Hoff-kerk”, en 'n ,DirkPostma-kerk"? Wie hierdie vraag bevestigend beantwoord, ontvang onmiddellik 'n wedervraag: „Is Christus verdeel? Is Paulus miskien vir julle gekruisig? Of is julle in die naam van Paulus gedoop?" (1 Kor. 1 : 13). Oortuigend blyk uit die hele Nuwe Testament dat één God slegs één volk kan hê, één Christus één liggaam, één Gees éẻn bouwerk, één Herder één kudde en één Bruidegom één bruid.

Watter konnotasie heg ons aan die belydenis aangaande ,die volharding van die gelowiges"? (Dordtse Leerreëls, hfst. 5). Moet dit slegs in individualisties-personele sin verklaar word, of sien dit ook op die kerk as totaliteit? Indien ons die eerste moontlikheid kies, word daar dan nie 'n kunsmatige skeiding gemaak tussen gelowiges enersyds en die kerk andersyds nie?, want die kerk is tog die gelowiges en die gelowiges is tog die kerk (Nederlandse Geloofsbelydenis, art. 27). ${ }^{20}$

Natuurlik bely ons die feilbaarheid van die Kerk. „Er is immers niets aan haar dat volmaakt, dat niet bedreigd, gebrekkig, problematisch is, dat niet steeds weer correctie en verbeteren zou behoeven". ${ }^{21}$ 'n Volmakte wese sonder sonde en dwaling ,,is God alleen, een tweede bestaat er niet". ${ }^{22}$ Tog impliseer hierdie werklikheid nie 'n opheffing van die waarheid van die leidende Gees nie. Die Kerk kan nie só dwaal dat hy radikaal vérdwaal nie. Dit sou die waarheidsleiding vn die Gees nie alleen minimaliseer nie maar inderdaad nihileer. ${ }^{23}$ Miskien is dit meer korrek om te stel dat die Kerk wel kán dwaal, maar slegs vir 'n tyd en dan ook ten opsigte van die nie-fundamentele geloofswaarhede. Indien toegegee word dat die Kerk vir altyd kan afdwaal van die hart van die Evangelie, word die koms en werk van die Here Jesus en die Heilige Gees volkome disputabel gestel. Ons verwerp 'n onfeilbare Kerk, maar bestaan daar nie 'n ondwaalbare Kerk nie? ${ }^{24}$

In die nuwe ekklesiologie speel die ekumene 'n groot rol. In hierdie verband word daar sterk nadruk gelê op die Bybelse motief dat ons alleen ,saam met al die heiliges" ten volle die breedte en lengte en diepte en hoogte van die liefde van Christus kan begryp (Ef. 2 : 18), En dan word die vraag gestel of elke kerkgroep op geīsoleerde wyse die volle waarheid van God se heilryke dade in besit kan kry. Reformatoriese Christene aanvaar die vrye Bybel asook dat die Bybel sy eie verklaarder is, maar hulle aanvaar ook, teenoor alle individualisme, 'n gesaghebbende kerklike interpretasie van die Skrif. Trouens, wat anders is 'n belydenisskrif?25

\subsection{Konfessionele vraag}

Beteken die aanvaarding van die moontlikheid tot kerkskeuring nie outomaties dat daarmee vele konfessionele probleme na vore tree nie? - afgesien nog van die vraag of dit nie 'n devaluering inhou van die belydenis aangaande die duidelikheid en genoegsaamheid van die Skrif nie. ${ }^{26}$ Die reformatoriese konfessies wil tog baie 
duidelik sowel formuliere van suiwerheid as van eenheid wees, terwyl dit tans dreig - as gevolg van die interpretasieprobleem - om oor te swaai in formuliere van ónenigheid. In Suid-Afrika en in Nederland het ons ook duidelike voorbeelde daarvan dat kerkskeuringe voorgekom het ondanks - sommige sal selfs sê: danksy - die formuliere van ecnheid, waardeur die konfessie onmagtig geblyk te gewees het om as hoeder en garansie vir kerklike eenheid te fungeer.

Daarby roep die konfessie ons op dat ons ons nie van die ware Kerk ,behoort te onttrek” nie, om die „eenheid van die Kerk (te) bewaar", dat die "wat hulle van die ware Kerk afskei... teen die ordinansie van God" handel (N.G.B. art. 28), dat ons ons nie van die ware kerk „mag afskei" nie (N.G.B. art. 29). Die probleem kom egter in al sy skerpte na vore wanneer daar 'n áántal ware Kerke (in die sin van „kerkgroepe") na vore tree, terwyl die een kerkgroep die waarheidsgestalte van die ander nie ontken nie. Dit is volkome begryplik dat, wanneer die Kerk voor hierdie ongerymdheid geplaas en in hierdie engte gevoer word, die onderskeiding van „meer en minder suiwer kerk" op die horison sou verskyn - 'n skema vreemd aan sowel die Heilige Skrif as die Belydenis. ${ }^{27}$

Ongetwyfeld handel die Confessio Belgica ón oor ",afskeiding" (art. 28), waaroor later meer. Frappant is egter die feit dat, terwyl daar slegs één maal gespreek word oor „afskeiding", nie minder nie as viér keer verwys word na "nié-afskeiding".

\subsection{Kerkregtelike vraag}

Die vraag word gestel of die tradisionele visie op kerkskeuring nie ook groot probleme na vore roep rondom die kerkregering nie. Is dit nie 'n alte maklike weg wanneer 'n groepie ,gesuiwerdes" hulle aan die groot liggaam onttrek nie, en is dit nie presies die teenoorgestelde van wat Paulus bedoel as hy sê: „Suiwer dan die ou suurdeeg uit"? (1 Kor. 5: 7, vgl. vs. 13). Is dít nie die suiwer Skriftuurlike weg dat die kerk die tugwaardiges vermaan en, wanneer nodig, afsny nie? Kan 'n Kerk sodanig verval dat 'n klein groepie lidmate die groot groep afsny? Is die motief by Paulus uittreding ò uitsetting?

Hierteenoor sou moontlik - as 'n soort skaakmatspel met tekste - verwys kon word na die vele onttrekkingstekste in die Nuwe Testament wat in hierdie saak ongetwyfeld 'n belangrike, so nie deurslaggewende rol gespeel het en nog speel - vgl. Rom. $16: 17,2$ Kor. $6: 14-18$, Gal. $1: 6-9,2$ Thess. $3: 14,1$ Tim. $6: 3-9$, Titus $3: 10-11,2$ Joh. $9-11$, Openb. $18: 4$. Na 'n noukeurige bestudering van hierdie tekste blyk onder andere die volgende: (i) Al hierdie tekste, met die uitsondering van twee (2 Kor. $6: 14-18$ en Openb. $18: 4$ ), handel oor 'n intra-kerklike (of intragemeentelike) situasie. ${ }^{28}$ Dit gaan steeds om die onttrekking van een - of meer - broeders, maar nooit roep Paulus 'n gemeente op om hom van 'n ander gemeente te onttrek nie (interkerklike situasie). Al was daar veel gebreke ten opsigte van die Nagmaalsvieringe in die Korinthiese gemeente (1 Kor. 11), nooit roep die 
Apostel ander geméentes op om hulle dáárom van Korinthe te distansieer nie; en al was die evangelieprediking en tug soms benede peil, ook dít was vir hom geen rede om tot kerkskeuring op te roep nie. ${ }^{29}$ Opvallend genoeg praat die Nuwe Testament nêrens van 'n valse kerk nie maar telkens weer van valse broeders. Bogenoemde tekste, handelende oor die onttrekking aan broeders, en nie gemééntes (of kerke) nie, kan dus nie simplisties van toepassing gemaak word om die verskeurde kerklike situasie van tans te motiveer of te legaliseer nie. Dit sou 'n sprong-eksegese en 'n logiese denkfout wees. Eerder kan die vraag gevra word of, terwyl Paulus skeuringe binne die een gemeente afgekeur het ( 1 Kor. 1 : 12-13), hy dit nie des te meer sou gedoen het wanneer die een gemeente hom van die ander gemeente afgeskei het nie. ${ }^{30}$ (ii) In 2 Kor. $6: 14-$ 18 en Openb. $18: 4$ gaan dit heeltemal nie oor die verhouding „ware kerk: valse kerk" nie, maar oor die verhouding ,kerk: wêreld" (2 Kor. 6, Gemeente: ongelowiges; Openb. 18, Godsvolk: Babilon) ${ }^{31}$ Dit is hoogs twyfelagtig om op hiérdie twee tekste 'n beroep te doen waardeur 'n kérkskeuring verdedig of regverdig kan word. (iii) Veels te weinig word rekening gehou met die feit dat die Nuwe Testament en die Nieu-Testamentiese skrywers nog vóor die situasie van kerklike verskeurdheid staan, en dat dit daarom eksegeties onverantwoord is om tekste wat slegs 'n eenheidssituasie ken en onbekend is met 'n kérklike verskeurdheid ágteraf op simplistiese wyse van toepassing te maak op 'n post-Bybelse ontwikkeling. . $^{31 a}$

Ook 1 Kor. $11: 19$ - „daar moet partyskappe onder julle wees" - mag nie op oorvereenvoudigende wyse misbruik word om 'n kérkskeuring te legaliseer nie. Hierdie teks staan binne die konteks van 'n „Is Christus verdeel?" ( $1: 13)$, en binne die raamwerk van die vermanende oproep tot eenheid rondom die nagmaalstafel. ${ }^{32}$


maar partyskappe (aьpereıs, vs. 19), en dit alles binne die raamwerk van die een onverdeelde Korinthiese gemeente. Paulus roep nie op tot kerkskeuring wat moet uitloop op twéé contra-kerke in Korinthe nie, nee, hy laat die moontlikheid oop van partyskappe binne die één gemeente, met die spesifieke bedoeling, „sodat die beproefdes onder julle openbaar kan word" (vs. 19). Hiermee is die legitimiteit én grens van die partyskappe aangedui. Die gemeente mag nie verdeel in ' $n$ Paulusgroep, Apollosgroep, Cefasgroep en Christusgroep nie (1 : 12), maar die "partyskap" - binne die een gemeente moet daarop bereken wees dat die „beproefdes openbaar kan word". ${ }^{33}$

2.6. Kerkhistoriese vraag

Ten slotte noem ons 'n historiese argument. Vir elkeen wat 'n sinvolle blik op die kerkgeskiedenis werp, skyn dit asof dit net nie aan die kerk gegéé is om één kerk te bly nie. 144 n.C., ${ }^{34} 1054,1517$, $1834,1886,1859$ - dit is almal datums wat van 'n smartvolle verlede getuig. Daarom is die probleem nie net: Hoe wórd die vele kerkgroepe weer een Kerk nie, maar ook: hoe voorkóm ons verdere kerkskeuringe? Dit is dan ook geensins verbasend dat daar van 
Roomse kant skerp kritiek op die Reformatoriese kerkontwikkeling gelewer word nie: „Ze hebben, losgeraakt van de moeder, onder elkaar ruzie gekregen die vaak niet geringer was dan die met de moeder. Ze hebben met hun eigen kinderen dezelfde bittere ervaringen moeten opdoen als hun moeder met hen". ${ }^{35}$ Fiolet spreek selfs van 'n ,fatale ontwikkeling". ${ }^{36}$ En selfs die grote Bavinck moes toegee dat in die Protestantisme sowel 'n ,kerkhervormend en een kerkontbindend element" aanwesig is. ${ }^{37}$ In hierdie verband hoort die woorde van Polman tuis wanneer hy praat van ,ongebreideld individualisme" en ,gezagloos subjectivisme". ${ }^{38}$

Veral in Holland sien ons baie duidelik hoedat hierdie standpunt 'n konsekwente en byna outomatiese ontknopingsproses ten gevolg het. Afgeskei van die Geref. Kerk in Nederland in 1944, beleef die Vrygemaakte Geref. Kerk tans weer nuwe pogings tot vrymaking. Ook die Geref. Kerk self staan op die rand van 'n skeuring. Ook die kerklike betrekkinge tussen Suid-Afrika en Holland is in die branding. 'n Mens hoef geen profeet te wees nie om te voorspel dat élke kerkgroep wat op die standpunt staan dat die kerk mág skeur, vroeër of later by so 'n krisissituasie móét uitkom. As ons dit nie wil aanvaar nie, is ons ò blind vir die toekoms, òf ons ken die geskiedenis van die kerk nie. Daarom gaan die stryd tans nie alleen om die eenwording van die kerkgroepe nie, maar om die bewaring van die (soms wankelende) bestaande eenheid. Geen wonder dat sommige nie veel heil daarin sien om die bestaande kerklike situasie te kontinueer nie, maar 'n uittog organiseer uit die bestaande kerklike strukture na 'n nuwe gestalte van kerk-wees. ${ }^{39}$ Te meer as ons op die neus gedruk word met die stelling: „Niet de eenheid van de kerk, maar de vraag of er in de nabije toekomst nog wel een kerk zal zijn, is het actuele probleem van de twintigste eeuw. De vraag naar de toekomst van de kerk is een levenskwestie".40

\section{Twee moontlikhede}

Ons het tot dusver in breë trekke twee tradisionele visies ten opsigte van kerkskeuring weergegee, wat ons hier kortliks herhaal.

\subsection{Die Kerk voor die oop situasie}

Hiervolgens staan die kerk altyd voor 'n oop situasie, voor 'n oop moontlikheid, naamlik dat die onmoontlike - kerkskeuring - kan en mag plaasvind. 'n Sodanig gedeformeerde situasie kan dus in die kerk ontstaan dat dit 'n plig word om ter wille van die waarheid die eenheid los te laat en die kerk te verlaat vir 'n ander. In die jongste studies oor die ekklesiologie word egter die valse dilemma van of die waarheid of die eenheid verwerp, en word daarop gewys dat die eenheid van die Kerk $\delta 6 k$ ' $n$ waarheid is, en miskien selfs 'n groter waarheid as die ander waarhede waarvoor dit dan opgeneem is. 'n Onenige Kerk is in die lig van die Nuwe Testament eenvoudig 'n onwaarheid."t

In hierdie visie van die kerk-voor-die-oop-situasie word kerk- 
skeuring soms as plig beskou, egter ná volbragte plig. Dit mag nie ligvaardig onderneem word nie; dit kan soms sektariese afmetinge aanneem; dit moet oor kardinale sake gaan; dit kan selfs sondig wees (al moet die kerkgroep nog gebore word wat in ootmoed sy afskeiding as sondig bely). Maar tog, so word gestel, kerkskeuring mag alleen dan geskied wanneer (i) duidelik blyk dat die "moeder" vals (waarin alles?) geword het, en wanneer (ii) die kerklike weg end-uit bewandel is maar die "moeder" geen gehoor gegee het nie.42

Daarby word dit dan gesien nie as breuk met die kerk nie, maar as voortsetting van die ware kerk. Eintlik breek die ánder weg, of liewer hulle word afgesny - al is dit ook 'n afsnyding sonder die lees van die afsnydings-formulier.

\subsection{Die Kerk voor 'n geslote situasie}

Hiervolgens kan kerkskeuring nooit plig wees of word nie, omdat dit die wese van die kerk aantas. ${ }^{43}$ Alle Christologie, Pneumatologie en ekklesiologie word op sy kop geplaas, omdat daar, net so min as wat daar sprake kan wees van 'n onheilige, onkatolieke, onchristelike en onapostoliese Kerk, net so min sprake kan wees van 'n onenige Kerk.

Sommige is bereid om sover te gaan deur toe te gee dat wanneer iemand (of 'n groep) deur die Kerk afgesny word, terwyl hy (hulle) tog in kerklike verbondenheid wil leef (extra ecclesiam nulla salus!, Cyprianus), die weg tot nuwe kerkformasie dan oopstaan, slégs dan (soos byvoorbeeld in die geval van Luther). Of hierdie "nuwe" kerk met die „ou" kerk in gemeenskap moet tree, is oop vir diskussie. Of is die "nuwe" outomaties in kerkverband met die „oue”, omdat die Kerk na sy wese één is? ${ }^{+4}$ Ander sal weer van oordeel wees dat selfs ná afsnyding die band met die "ou" kerk behou moet word - al beteken dit ook 'n lydensweg -, en wel in navolging van Jesus wat nooit die Godsvolk van die ou verbond verwerp het nie maar hulle liefgehad het tot die einde toe (Joh. $13: 1)$.

In hierdie stadium moet ons egter twee vrae onder oë sien, naamlik: (i) Wat is ons interpretasie van die Nederlandse Geloofsbelydenis art. 28 , en (ii) wat is ons interpretasie van die kerkhistoriese gebeure rondom 1517 en 1859 ?

In art. 28 van die N.G.B. is tog baie duidelik sprake daarvan dat "dit die amp van die gelowige (is) ... om hom af te skei van diegene wat nie tot die Kerk behoort nie..." Word hiermee nie outomaties, sonder twyfel en teëspraak die weg geopen vir verantwoorde kerkafskeiding nie?

Polman het oortuigend aangetoon, so het reeds geblyk, dat die belydenis insake die ware en valse Kerk nie vanuit 'n swart-witskema geinterpreteer moet word nie ${ }^{44 a}$ - tensy ons bereid is om die Belgica onhistories te verklaar. ${ }^{45}$ Wat is die konnotasie van die woorde in die Belydenis: ,diegene wat nie tot die Kerk behoort nie"? Sien dit op ongelowiges (as ons dan wél onhistories wil wees!) of op afgedwaalde broeders (resp. kerkgroepe)? Indien ons in ge- 
dagte hou dat die Reformatore die Roomse Kerk as valse kerk bestempel het, kan die legitieme vraag gestel word of ons nie aan bogenoemde woorde - agteraf - 'n betekenis toeskryf wat daaraan vreemd is wanneer ons dit onveranderd van toepassing maak op ander Reformatoriese kerkgroepe nie. ${ }^{46}$ Daarby is die opvallende bewoënheid in die N.G.B. ten opsigte van die bewaring van die eenheid (drié keer) in skerp „kontras” met die één keer se verwysing na "afskeiding".

Myns insiens bied die ,afskeidings"-woorde geen goedkoop opening vir 'n kerkskeuring nie.

Die tweede vraag - 'n interpretasie van die gebeure rondom 1517 en 1859 - is ewe delikaat. Was hierdie kerkskeidinge legitiem?

Ten opsigte van 1517 het ons reeds geantwoord dat dit nooit Luther se bedoeling was om die Kerk te skeur nie. Sy weg tot reformasie het daartoe gelei dat hy c.s. deur die Roomse Kerk uitgeban is. Of al die reformatore hierdie visie van Luther toegedaan was, is 'n ope vraag. Dit kan egter nie ontken word nie dat in die na-reformatoriese periode 'n koers ingeslaan is waarin die reformatoriese bewoënheid oor en worsteling ter wille van die eenheid van die kerk grotendeels ontbreek het. Pas in die twintigste eeu, met die opkoms van die verskillende ekumeniese beweginge - intensief in die Gereformeerde Ekumeniese Sinode en ekstensief in die Wêreldraad van Kerke - is die reformatoriese worsteling vir die eenheid van die Kerk weer opgeneem.

Ten opsigte van die gebeure rondom 1859 is 'n billike, objektiewe, verantwoordelike en Christelike antwoord moeilik te gee. Elke kerkgroep regverdig sy eie saak. Weinig vind veel fout en skuld by hulleself - dit word bewys deur die verskillende kerkhistoriese handboeke uit die verskillende groepe. Dit kan ook moeilik anders verwag word - want elkeen is regter in sy eie saak. Indien ons 'n beoordeling moet waag, moet ons sê dat wat die ,afskeiding" van die Geref. Kerk betref, sowel in Transvaal (van die Hervormde Kerk) as in die O.V.S. en Kaapland (van die N.G. Kerk), daar van afsnyding deur kerklike tug nog nie sprake was nie - tensy ons, soos die Heidelbergse Kategismus (antw. 85), afsnyding en ekskommunikasie identifiseer. ${ }^{47}$ Die Gereformeerdes het wel die reformatoriese weg binnekerklik gevolg, maar die vraag word met reg gevra of hulle lank genoeg - met herhaalde appèlskrifte - aangehou het. Andersyds kan gevra word of die Hervormde Kerk en N.G. Kerk nie in menige opsig star en strak, sonder begrip en bewoënheid opgetree het nie, en op hierdie wyse die kloof vergroot, verskerp en geforseer het. ${ }^{47 a}$

Tog sal selfs die beste interpretasie van die kerkgeskiedenis en wie het bowendien die charisma ontvang om die laaste bevrydende woord oor die geskiedenis te spreek? - ons nie help om die weg na eenheid te vind nie. Dít sal alleen moontlik wees langs die weg van skuldbelydenis, vergifnis en versoening. Indien ons as Afrikaanse kerkgroepe nie bereid is om ons skuld voor God en aan mekaar te bely nie (vgl. Jak. $5: 16$ ); indien ons nie bereid is om 
mekaar te vergewe soos God in Christus ons vergewe het nie (Ef. 4:32); indien ons nie bereid is om ons met ons broeder te versoen nie (Matt. $5: 23-24$ ), sal al ons gesprekke oor kerklike eenheid op 'n fiasko uitloop. Kerklike eenwording ,is noch de ,terugkeer' van de ene kerk naar de andere, noch de ,uittocht' uit de ene naar de andere ..., doch de gemeenschappelijke ,ommekeer', conversie van alle kerken naar Christus en zo naar elkaar: niet de onderwerping van de ene kerk aan de andere, maar aan beide zijden de ommekeer en de wederzijdse aanvaarding van de gemeenschap in wederzijds schenken en ontvangen". 48

Hierdie ,terugkeer" moet m.i. sowel op Sinodale as plaaslike vlak ter sprake kom, indien ons hele strewe nie in die lug wil hang nie. ${ }^{48 a}$

\section{4. 'n Genuanseerde kerk?}

Ons ekklesiologiese probleem kulmineer hierin: Kies ons vir die ,oop-visie", beteken dit 'n onkeerbaar repeterende breuk terwyl die Nuwe Testament nie 'n verskeurde kerk ken nie. Kies ons vir die „geslote-visie", dreig die gevaar van 'n modaliteite kerk - eweneens onskriftuurlik. Die vraag ontstaan of daar ' $n$ derde moontlikheid is, naamlik dié van 'n genuanseerde kerk.

Laat dit vooraf baie duidelik wees wat ons hiermee nié bedoel nie: Ons bedoel met - die vraag na - 'n ,genuanseerde kerk" nié 'n modaliteite-kerk (of 'n ,hotelkerk", soos H. N. Ridderbos dit graag noem), soos byvoorbeeld te vind is in die Nederlandse Hervormde Kerk waar opperste vrysinnigheid en radikale ortodoksie onder een dak saamgevoeg is nie (ecclesiola in ecclesia).

Ons bedoel ook nie 'n figure-kerk waar bepaalde persone tot heilbrengers verhef word of waar dit dreig om te gebeur nie (vgl. die oorsprong van die naam Reddersburg). Daarom verwerp ons, op grond van 1 Kor. 1 : 12-13, radikaal 'n Petruskerk, 'n Pauluskerk, 'n Apolloskerk, maar eweneens 'n Lutherkerk, Calvynkerk, ook 'n Jan-van-Riebeeck-kerk, Postma-kerk en Van-der-Hoff-kerk. Die Kerk is ekklesia van God - en van Christus -, of hy is geen ekklesia nie.

Die vraag ontstaan egter of daar nie tóg sprake kan wees van 'n genuanseerde Kerk nie, ja skerper nog: of die Kerk nie alleen dan kan bestaan - as één Kerk - wanneer daar sekere wettige en Skriftuurlike nuanses toegelaat word nie - 'n Kerk dus sonder dogmatiese en konfessionele relativisme en indifferentisme. ${ }^{49}$ Ons bedoeling kan ons soos volg formuleer: Indien daar in die Nuwe Testament ruimte was vir 'n Lukas en Johannes, 'n Paulus en 'n Jakobus, elk met sy eje aksente, dan behoort daar ook in die NieuTestamentiese gemeente ruimte te wees vir 'n Tertullianus en Origines, ' $n$ Athanasius en Augustinus, 'n Calvyn en 'n Luther, 'n Berkouwer en - 'n Barth? - waarmee geensins beweer word dat álle konsepsies van lg. teoloë as waar aanvaar moet word nie. ${ }^{50}$ Daar was nog altyd 'n speelruimte gelaat ten opsigte van nie-beslissende punte, byvoorbeeld die doop vir die dooies (1 Kor. 15:29), die preek vir die geeste in die gevangenis (1 Petr. $3: 19$ ), die deelgenootskap 
aan die goddelike natuur (2 Petr. $1: 4$ ), die salf van siekes deur ouderlinge (Jak. $5: 14$ ), die groter werke, as dié van Jesus, wat die gelowige sal doen (Joh. 14:12), die vervulling van die profesieë (Chiliasme), infra- en supralapsarisme ens. ens.51 Sonder dat ons mekaar as ketters afskryf, word daar ten opsigte van veel in die Skrif 'n wettige speelruimte gelaat, solank dit nie die hart van die evangelie van die koninkryk aantas nie, naamlik dat Jesus van Nasaret die Messias, die Seun van God, die Here is, soos bewys in sy kruisiging en opstanding.

\subsection{Kerk en Konfessie}

Wie al 'n dogmageskiedenishandboek onder oë gehad het, moet erken dat ,de legitieme pluraliteit van die leer was immers in de vroege kerk aanzienlijk groter dan in de latere". ${ }^{22}$ Maar dan tog só 'n pluraliteit waarby in die kerk nie ,alle geeste versamel word nie, maar die geeste onderskei word". ${ }^{53}$ Dit gaan dus enersyds om die afwysing van absolute perfeksionisme, soos by vele doperse rigtinge, maar waarby andersyds die heiligheid van die Kerk nie afgesleep word nie. ${ }^{54}$

Die hele probleem spits hom hoofsaaklik toe op die vraag na 'n gereduseerde, gekonsentreerde belydenis, die vraag na die skopus. Hierdie tema is indringend aan die orde gestel deur $\mathrm{H}$. Volten in sy boek „Rondom het Belijden der Kerk". ${ }^{5}$ Hierin betoog hy dat „de belijdenis der toekomst zal aldus een in Christus geconcentreerde moeten blijven, maar gereduceerd". ${ }^{56}$ Want ,wie de drie formulieren als grondslag voor de kerk aanneemt en blijft aanvaarden, kan niet anders dan de kerkelijke verdeeldheid sanctioneren tot Christus's wederkomst toe en handelt daarmee in strijd met het schriftuurlijk patroon van de kerk... De fout, die aan ons kerkelijk leven ten grondslag ligt, is niet maar dat men Geelkerken en Buskes schorste, maar dat mannen als Luther en Spurgeon er geen plaats in hebben". ${ }^{57}$ Ook Berkouwer is van mening dat ons met die vraag na konfessionele reduksie aan "één van die diepste vrae raak in verband met die eenheid van kerk". ${ }^{58} \mathrm{Hy}$ meen ook dat $\mathrm{H}$. N. Ridderbos self onder die indruk is "van die noodsaaklikheid van die konsentrasie" (van die belydenis).$^{59}$

Ongetwyfeld ken die Heilige Skrif self so 'n konsentrasie, naamlik dat die koninkryk van God gekom het met die koms van Jesus, die Messias, die Seun van God, die Here (Matt. $16: 16$, Joh. $20: 31$, 1 Kor. $12: 3$ ). Hiér is die cor ecclesiae! Die Antichris sal ook nie uitgeken word aan die áántal dogmas wat hy ontken nie, maar wel hierin dat hy hierdie ,sentrale dogma" loën, wanneer hy ontken dat Jesus van Nasaret die Messias is en wanneer hy die Vader en die Seun loën ( 1 Joh. $2: 22$ ), wanneer hy nie bely dat Jesus Christus in die vlees gekom het (2 Joh. 7). Alle Gereformeerde kerke oor die wêreld is dit ook hierin eens dat ,the Gospel of Jesus Christ is the core and apex (of the Scriptural truth) ...".0

Simptomaties in hierdie verband is die strewe van verskillende kerkgroepe om te kom tot 'n nuwe belydenis, waaraan daar allerweë 
sterk behoefte bestaan.60a En dan nie eerstens as gevolg van (vermeende) besware teen wat in die huidige belydenisskrifte wél staan nie, maar teen wat daarin nié staan nie. Dit kan byvoorbeeld nie ontken word nie dat die hele gedagte van die koms van die koninkryk van God, wat in sowel die Ou as Nuwe Testament 'n prominente plek inneem, nie genoegsaam in die belydenisskrifte op die voorgrond staan nie. ${ }^{61}$

\subsection{Kerk en Kerkregering}

Die vraag dring homself na vore of die Skrif slegs een outoritatiewe en onveranderlike vorm van kerkregering ken, i.c. dan die presbiteriale. ${ }^{62} \mathrm{R}$. Boon meen dat dit soos 'n paal bo water staan „dat in tegenstelling tot de gangbare mening Calvijn allesbehalwe de vader van de presbyteriale kerkstructuur is geweest. Zijn ambtsopvatting is veeleer diametraal tegenovergesteld aan een presbyteriale structuur, daar zij een uitgesproken episcopaal karakter draagt".63 Nauta het hierdie stelling enigsins weerspreek deur te wys op die eensydigheid by Boon, aangesien die materiaal ten gunste van ' $n$ presbiteriale opvatting by Calvyn oorvloediger en kragtiger van strekking is as wat Boon laat uitkom. ${ }^{6+}$ In navolging van $\mathrm{H}$. Bavinck $^{65}$ het egter 'n hele reeks gereformeerde teoloë begin wys op die gebreke aan 'n louter presbiteriale stelsel. Plomp meen dat 'n episkopaalse element in 'n presbiteriaal-sinodale orde toegelaat kan word en dat dit nié onbybels of oncalvyns of ongereformeerd is nie.66 N. J. H(ommes) meen dat 'n mens uit die Skrif geen veto kan haal vir 'n episkopaalse sisteem van kerkregering nie, ${ }^{67}$ terwyl Volten oordeel dat ,onze synodaal-presbyterale kerkorde zo niet zal kunnen blijven staan".68

Terwyl Vaticanum II - volgens Küng - gelukkig vermy het om die episkopaalse kerkinrigting ,tot criterium voor de benaming ,kerk' te maken", ${ }^{69}$ het die Gereformeerde Ekumeniese Sinode $66 \mathrm{k}$ nie 'n absolutistiese standpunt met betrekking tot die kerkregering ingeneem nie: „Because of the diversity in the forms of government of the Reformed Churches, uniformity of church polity cannot be stressed as a fundamental requisite...".70

Dit alles beteken nie dat dogmatiese en kerkregtelike verskille as van weinig belang geignoreer, gebagatelliseer of as irrelevant voorgestel mag word nie, inteendeel, hulle moet uitgeveg word. Kenners is van oordeel dat sowel die eenheid tussen Rome en Reformasie as dié binne die Reformasie baie nou saamhang met die oplossing van die vraag na die juiste kerkregering. ${ }^{71}$

\subsection{Kerk en Liturgie}

In die basisformule van die Gereformeerde Ekumeniese Sinode kom geen enkele verwysing voor na die suiwerste vorm van liturgie nie. ${ }^{72}$ Hierin het die Reformatore ook groot soepelheid toegelaat. Calvyn het byvoorbeeld die Franse vlugtelinggemeente in Basel, wat gaste by die Lutherse Kerk was, geadviseer dat die een by die ander 
moet aanpas in al die seremonies wat geen beslissende invloed op die belydenis van die geloof het nie, sodat die eenheid van die kerk nie deur ons te grote gestrengheid of beangstheid verstoor word nie. Calvyn wou die eenheid veel eerder soek in die leer en gevoelens, as om eiewys vas te byt aan die noukeurige ooreenkoms in die vorm van die erediens. ${ }^{73}$ Die ware kerk het vir Calvyn ook nie net bestaan uit die Geref. Kerk nie. „De Engelse, episcopaalse kerk, die Lutherse, zelfs de gemeenten der Waldenzen en Bohemers worden als ware kerken erkend". ${ }^{74}$ Ware kerke was vir Calvyn álle kerke wat aan die gestelde kenmerke voldoen het. „Daaronder worden alle kerken der Reformatie begrepen, al is er verschil in zuiverheid zowel in de leer als in de liturgie". ${ }^{75}$

Floor het in 'n deeglike studie aangetoon dat in die vroeë kerk ,alles nie so georganiseer (was) as in die gevestigde kerk van hierdie tyd nie. Ons sien dat die lidmate van die jong kerk aktief deelgeneem het aan die godsdiensoefening. 'n Groot mate van vryheid het in die oud-Christelike erediens voorgekom. Die hele gemeente was in die erediens werksaam". ${ }^{76} \mathrm{Hy}$ meen ook dat daar ,geen prinsipiële beswaar is om ook die Sondagse byeenkomste van die gemeente op hierdie lees te skoei nie" 77 (vgl. 1 Kor. 12-14).

\section{Slot}

Ons word deur die Woord van God, deur God Self en deur Christus Self, opgeroep om opnuut diensbaar te wees aan die koms van sy koninkryk. ${ }^{78}$ In die uitvoering van hierdie roeping sal 'n kerk wat met verdeelde fronte veg die een verlies na die ander moet aanteken. En geld hier nie ook die woord van Jesus dat ,elke koninkryk wat teen homself verdeeld is, verwoes word" nie? (Matt. 12:25). Ons moet ons kinders help om - ook sonder konsentrasiekampe die jaar 2000 binne te gaan as die een onverdeelde Godsvolk. Want "tot de splitsing van de kerk, had het niet mogen komen, onder christenen niet. Een kerksplitsing is een schandaal en een schande". ${ }^{9}$ Ons kan byvoeg: 'n voortgesette skeuring vergroot hierdie skandaal en skande. Dit maak die boodskap van die kerk al hoe minder geloofwaardig (Joh. 17: 21).

Gelukkig word die oproep tot kerklike eenheid in Suid-Afrika al hoe meer gehoor. ${ }^{\text {so }}$

Ten opsigte van sekere aspekte is in hierdie opstel - huiwerend en tastend - ' $n$ ander weg vir die kerk gesoek as wat in die nareformatoriese ekklesiologie die geval was: 'n weg terug na die Reformasie, of beter: terug na die Skrif en na Christus. En 'n weg vorentoe: na die onbelemmerde en glorieryke koms van die koninkryk van God.

J. H. van Wyk (Johannesburg). 


\section{VERWYSINGE}

1 "Het is waarlijk geen wonder, dat altijd weer de vraag aan de orde is gesteld, niet mar, hoe we de verdeeldheid eventueel kunnen verklaren, maar of ze mogelijk is". "Zó duidelijk komt dat uit het ganse N.T. op ons af, dat alle verscheurdheid, breuk en schisma binnen "de kerk", binnen Christus' kerk, die Zijn lichaam is, alleen maar een ridicule, onmogelijke gedachte schijnt te kunnen zijn, niet maar een te betreuren feit, maar een neen, dat het ja weerspreekt en aantast", G. C. Berkouwer: De Kerk. I. Eenheid en Katholiciteit, J. H. Kok N.V., Kampen, 1970, p. 32-33. Die boek van Berkouwer het my bereik nadat hierdie opstel voorgedra is op 'n interkerklike samespreking, Johannesburg, 8 Junie 1970 Opm.: (i) So ver moontlik is met „Kerk” (hoofletter) die universele Kerk bedoel en met "kerk" (kleinletter) die plaaslike kerk. Dit is egter onmoontlik om beide radikaal van mekaar te skei. (ii) Dubbele hakies is van my - v.W. (Die leser word aangeraai om éers die opstel in sy geheel deur te lees en daarná die voetnote te raadpleeg).

2 H. Bavinck: Gereformeerde Dogmatiek IV, J. H. Kok, Kampen, 1928 (dr. 4), p. 360. Bekend is A. Kuyper, H. H. Kuyper en V. Hepp se pluriformiteitsbeskouing, vgl. C. Veenhof: Volk van God. Enkele aspecten van Bavincks kerkbeschouwing, N.V. Buijten en Schipperheijn, Amsterdam, 1969, p. 122-124. Schilder het hierdic visie skerp bestry, ,ze is nu een overwonnen stand. punt", idem p. 124. Vgl. ook Berkouwer: a.w., p. 61-93. Vir Bavinck oor die Afskeiding vgl. Veenhof: a.w., 127-135.

3 In Het Dogma der Kerk, Groningen, 1949, p. 510. Praamsma aanvaar egter twee voorwaardes: (i) daar moet sprake wees van 'n valse kerk, en (ii) die kerklike weg moet end-uit bewandel word (idem). Vgl. ook Gijsbertus Voetius: De Zichtbare en Georganizeerde Kerk, J. H. Kok, Kampen, 1902, p. $100-111$.

4 K. Dijk: Korte Dogmatiek, Kampen (1965?), p. 271. Vgl. Barth: Dogmatics in Outline, London, 1960: „Of course, schism cannot be excluded; it may be objectively necessary" (p. 144). Maar: "If we believe in the Holy Spirit in this Church, then even in the worst case we are not absolutely separated from the other congregations" (p. 143). „There are not substantially different Churches" (p. 144).

5 Handelinge van die Geref. Kerk in S.A., Potchefstroom, 1967, p. 364.

6 Die Handelinge is tans nog nie beskikbaar nie, vgl. Die Kerkblad, 13 Mei 1970, jg. 73, nr. 2049, p. 6.

7 Vgl. B. Duvenage in: Die Koninkryk van God, Potchefstroom, 1969, p. 298: "Afskeiding kan ook roeping wees"; B. Spoelstra: Beknopte Kerkgeskiedenis vir Katkisasie, Pro Rege-Pers, Potchefstroom, 1964 (2e): Wanneer 'n kerk hardnekkig weier om sy verkeerdhede te bely en daar van af te sien, „dan moet so 'n kerk ter wille van die gewete voor God verlaat word om tot 'n suiwere kerkformasie oor te gaan"; W. J. de Klerk en J. H. van Wyk: Woord en Antwoord, Pro Rege-Pers Bpk., Potchefstroom, 1963, p. 130: „As die valsgeworde kerk weier om hom te reformeer, moet mens dit laat vaar en 'n suiwer kerk vorm".

Vgl. ook W. D. Jonker: Aandag vir die Kerk, Potchefstroom, s.j., p. 40: „Dit beteken nie dat daar nie so iets as 'n geregverdigde en selfs noodsaaklike afskeiding bestaan nie, want dit is die plig van die gelowige om 
hom van die kerk af te skei as die kerk tot valse kerk verval het (vgl. art. 29, Nedl. (Geloofsbel.)". Vgl. die gereformeerde kerkhistoriese interpretasie van 1859: „wat dan nie beteken het 'n nuwe kerkstigting nie”, G. C. P. van der Vyver: Professor Dirk Postma, 1818-1890, Pro Rege-Pers Bpk., Potchefstroom, 1958, p. 310 (vgl. ook 261), en B. Spoelstra: Die „Doppers" in Suid-Afrika 1760-1899, Nas. Bockhandel, Johannesburg, 1963, p. 141: „Hierdie afskeiding was nie 'n daad van Postma nie. Hy het inteendee] juis alles in sy vermoë gedoen om die deure van die Transvaalse Staatskerk vir hom en dic C.A.G. Kerk geopen te kry en om 'n skeuring te verhoed". A. D. Pont oordeel dat dit duidelik is dat "'n kerklike afskeiding wat plaasvind oor die sing van Gesange alleen, nié volgens die reformatoriese teologie of die Belydenisskrifte regverdigbaar is nie", ' $n$ Oorsig van die Algemene Kerkgeskiedenis en die Geskiedenis van die Nederduitsch Hervormde Kerk van Afrika, N.H.W.Pers, Krugersdorp, 1968, p. 206. Gereformeerde kerkhistorici het m.i. oortuigend aangetoon dat dit nie nét 'n gesangekwessie was nie. Sien ook punt 3. 2. van hierdie opstel.

8 H. Berkhof: Geschiedenis der Kerk, Nijkerk, 1955(6), p. 173. Ewencens oordeel J. D. du Toit: „Die bedoeling van Luther was aanvanklik nie om 'n nuwe kerk te stig nie", Versamelde Werke VII, Johannesburg, 1961, p. 505, en Berkouwer: "... omdat Luther en Calvyn er met grote stelligheid van overtuigd waren dat ze niet een ,nieuwe' kerk willen stichten", De Kerk, a.w., p. 229. Luther self sê: „Ik geloof, dat er op aarde is cen heilig groepje, een gemeente van enkel heiligen..., zonder secte of schisma” (p. 82), en: „Daarom hebben allen zich uitgeschakeld en afgezonderd, die niet door het Evangelie en vergeving van zonden, maar door hun goede werken heiligheid zoeken en willen verdienen" (p. 83), De Grote Catechismus (vert. P. Boendermaker), Kok, Kampen, 1965; die Evangeliese groep had die „ou belydenis", en was daarom die „ou, ware kerk", "for whoever thinks alike and holds alike with the old church, he belongs to the old church", by Reinhold Seeberg: Textbook of the History of Doctrines II, Baker Book House, Michigan, 1964, p. 295, voetnoot 2. Hans Küng gee toe dat kerksplitsing ook kan gebeur „vanuit de eerlijke overtuiging dat met anders het evangelie van Jezus Christus zelf zou verraden", De Kerk, Paul Brand, Hilversum, 1967, p. 317.

9 Institusie, W. D. Meinema, Delft (dr. 3), IV, 2, 12. Nie sonder rede nie noem Calvyn dat hoewel die godsdiens ten tyde van die profete "deels verag en deels besmet" was, die profete tog nie ,nuwe kerke opgerig het nie", IV, I, 18. Tereg sê Berkhof dat die verdeeldheid van die Godsvolk teruggevoer moet word tot die skeuring van Juda en Israel, maar dat God tog weer die eenheid van die twee bewerkstellig het, Gods éne kerk en onze vele kerken, Nijkerk, s.j., p. 22-27.

10 In Ex Auditu Verbi, J. H. Kok N.V., Kampen, 1965, p. 131-156. Vgl.: „Calvijn, zo poneert Ganoczy, zou er dan ook nooit aan hebben gedacht de Kerk, de enige, die hij kende, te verlaten, hoe ziek deze ook was. Hij zou nooit een andere kerk stichten", C. van der Woude: Het Beginsel van de Collegialiteit bij Calvijn en het Tweede Vaticaans Concilie, J. H. Kok N.V., Kampen, 1966, p. 6. Verder: W. Nijenhuis: Calvinus Oecumenicus. Calvijn en de Eenheid der Kerk in het licht van zijn Briefwisseling, 's-Gravenhage, Martinus Nijhoff, 1959, veral p. 275-308. 
11 By Nauta: idem, p. 154. Vgl. Institusie, IV, 13, 14. „Calvijn was zijn tijd ver vooruit en hij was zelfs ons ver vooruit. Hij zocht in de eerste plaats de éne kerk. Ook tegenover Rome wou hij geen nieuwe kerk oprichten; hij bedoelde de bestaande kerk die tot valse kerk geworden was, te vernicuwen en de oude kerk, de kerk van de apostelen en van die kerkvaders voort te zetten” (p. 195). „Toen de kerk toch uiteen viel, hecft hij dan ook alles gedaan, om de eenheid in de leer te herstellen" (p. 197), H. Volten: Rondom het Belijden der Kerk, J. H. Kok N.V., Kampen, 1962. Ook D. W. Kolfhaus attendeer hierop: „Das heilige lleimweh nach der Einheit der Kirche, auch der sichtbaren Kirche, darf den Christen nicht verlassen. In sciner praktischen Arbeit und grundsătzlich war Calvin ökumenisch" (352). "Soviel is deutlich, dass für Calvin die Kirche Christi nicht zusammenfält mit einem einzelnen und einzigen Institut" (361), Vom christlichen Leben nach Johannes Calvin, Neukirchen Kreis Moers, 1949. Die vraag is egter in hoeverre daar (selfs) by die Reformatore i.c. Calvyn, 'n klerikalistiese en konsiliaristiese kerkbeskouing geheers het, waardeur die Kerk tot 'n groot mate geidentifiseer is met die ampsdraers (en kerkvergaderinge), sodat, toe die kerkvergaderinge gedwaal het, outomaties gekonkludeer is dat die Kérk gedwaal het en daarmee die weg tot skeuring oop was. Calvyn aanvaar tog dat daar nog "kerke" by "Rome" te vind is! (IV, 2, 12). So kan prof. Dijk ook daarop wys dat die Reformasie nooit beweer het "dat in Rome niets meer van die kerk is; men zou dan kunnen zeggen, dat de gestalte, de vorm, de regering enz. van de kerk vals is geworden..."; en: "...om in de weg van Afscheiding of Doleantie het verband met de ,regering der kerk" te breken...", Korte Dogmatiek, a.w., p. 271. Die vraag wat hier lewensgroot verskyn, is: Is dit teologies en eksegeties verantwoord om te beweer dat wanneer ' $n$ kerkvergádering gedwaal het daarmee outomaties die Kérk gedwaal het? Is die Kerk nie méer as sy vergaderinge nie? En kan kerkvergaderinge hulle nie ook na verloop van tyd bekér van hul dwaalweë nie?

12 Onze Nederlandse Geloofsbelijdenis, Franeker, s.j., p. 229-382.

13 Hierdie aspek behoort m.i. tot, wat ons kan noem, "oneintlike" ekklesiologie, want net so $\min$ as wat ons sou kon handel oor die "onheiligheid" en „onkatolisiteit" en „onchristelikheid" van die Kerk, net so min behoort dit - cintlik - te gaan oor die "onenigheid" - die plig daartoe — van die Kerk.

14 Tiperend van 'n ,fatalistiese" ekklesiologie is m.i. die volgende: „Dat in een zelfde land, onder een zelfde volk zoveel kerken zijn, is te betreuren, maar het kan niet worden verholpen. Zolang wij met de zonde te kampen hebljen, zal het zo blijven. Dat moge ons een oorzaak van droefheid wezen; wij mogen er om treuren en het mag ook de kracht van het Christendom verzwakken; er is echter niets aan te veranderen", T. Hamersma: De Katechismus in 52 Predikaties, Nasionale Pers, Bloemfontein, 1919, p. 203. Verder ook gemotiveer met die ,uitvlugte” van die „onsigbare kerk” (201), „meer suiwer kerk” (203), eskatologiese verwagting (203). Anders by S. J. van der Walt: "Dit is duidelik dat ons nie maar kan berus in die verskeurde toestand warin die kerk van Christus vandag op aarde verkeer nie... Ons mag nie maar alle verdeeldheid goedpraat met die idee van die pluriformiteit van die kerk nie..." (al ken hy ook "'n egte soort 
pluriformiteit"), Geloofsleer en Sedeleer, o.a. by Pro Rege-Pers Bpk., Potchefstroom, s.j., p. 177.

15 Vgl. Veenhof: a.w., p. 119-126 en Berkouwer: a.w., 37-43 („onbegaanbare wegen", 44). Op verskillende plekke in sy boek oor die kerk speel die christologiese motief 'n belangrike rol: „De onmogelijkheid om het enkelvoud van de kerk te vervangen door het meervoud, wordt in het N.T. volstrekt bepaald door het uitzicht op de ene Heer der kerk" (47); "Het is Zijn nabijheid, die het "schisma" in het lichaam buitensluit, niet als een óok te honoreren secundair gevolg, maar vanwege de aard van Zijn Heer en Verlosser zijn” (109); „Het ene leven der gemeente wordt in een dringend vermaan - in Christus - wéggeroepen van en opgeheven uit schisma en twist vanwege de eenheid van het lichaam. Hier valt niets meer te tolereren en is niets meer acceptabel..." (110 - mees opspraakwekkende uitspraak); „Daarin treft ons dan telkens weer, ook in diepgaande controversen, het gezamentlijk gebruiken van dezelfde woorden, nu de continuiteit met Christus als Koning van Zijn kerk in verbandt wordt gebracht" (210), en „men zou de vraag kunnen stellen of deze concrete kerkelijke continuiteit ((met Christus)) in de Reformatie wellicht verloren ging of altans verduisterd is geworden" (211).

16 Praamsma in: Het Dognia der Kerk, a.w., p. 506.

17 „Zou het kunstig ene lichaam van Christus ooit uiteen mogen vallen in ledematen die, ofschoon ze slechts in het geheel mooi en zinvol zijn, nu cen mogelijk-onogelijk leven leiden in de gescheidenheid?", Küng: De kerk, a.w., p. 312.

17a Vir Paulus is die mees karakteristieke omskrywing van die doop die waardeur die doop aangedui word "als de intrede van het door Christus vertegenwoordigende levensverband en daarmee tevens als de inlijving in zijn lichaam" (p. 447); „De functie van de doop bestaat dus daarin, dat hij de dopeling in deze corporatieve (,Iichaams"-)eenheid tussen Christus en de zijnen inlijft of inplant, Rom. 6 : 5" (p. 450), Herman Ridderbos: Paulus. Ontwerp van zijn Theologie, J. H. Kok N.V., Kampen, 1966. Juis daarom is dit onmoontlik dat wanneer 'n lidmaat uit 'n gemeente vertrek (met attestasie), hy ,in wese kerkloos" kan wees, T. T. Spoelstra in Handleiding by die Kerkorde van die Geref. Kerk in S.A., Pro Rege-Pers Bpk., Potchefstroom, 1966, p. 490. Vgl. H. Steen: De Kerk, J. H. Kok N.V., Kampen, 1936, p. 112: „Degenen, die waarlijk geloovigen zijn, zijn - ook al behooren ze tot een andere „Kerk", in diepsten zin lid van onze Kerk".

18 Küng, idem, p. 312; vgl. 233, 276-277. Vgl. hier ook H. Berkhof: De-1eer van de Heilige Geest, G. F. Callenbach N.V., Nijkerk, 1965 (2), 45-70; H. N. Ridderbos: Het Woord, het Rijk en onze Verlegenheid, J. H. Kok N.V., Kampen, 1968, 166-177, en Uppsala 1968, J. H. Kok N.V., Kampen, -32-43. Berkouwer noem die vraag of die Heilige Gees die kerk so lank in die steek kon laat en aan dwaling en verval prysgegee het 'n ,allèrdiepste vraag ten aanzien van die continuïteit der kerk", De Kerk, a.w., p. 213. Hy verwys ook na Erasmus se uitspraak i.v.m. die kontinuiteit van die kerk (teenoor Luther): „Wer könnte glauben, dasz dieser Geist viele hundert Jahre lang einen Irrtum seiner Kirche absichtlich übersehen habe" (idem 224-225, noot 124).

Daarom is die vraag urgent of dit moontlik sou kon gewees het dat die 
Heilige Gees slégs die eerste ses Konsilies van die Kerk „in alle waarheïd” gelei het om dit daarna - vir hoclank? - aan eie insig oor te gelaat het, vgl. P. J. S. de Klerk: Gereformeerde Simboliek, Pretoria, p. 33: „Die Gercformeerdes aanvaar oor die algemeen die beslissinge van die eerste ses ekumeniese konsilies". Vgl. Calvyn oor die gesag van die Konsilies, Institusie, IV, 9, 1-14. Dit is vanselfsprekend dat die vraag homself na vore dring dat as God se beloftewoord selfs vandág nog deur Israel se ontrou nie kragteloos gemaak kan word nie (Rom. 9-11), sou Sy trou dan óoit deur die ontrou van die Kerk opgehef kon word?

19 Tereg wys Berkouwer 'n outomasistiese eenheids- en kontinuïteitsgarandisme af: „in een concrete gemeente (was) van een vanzelfsprekendheid van deze cenheid en liefde geen sprake"; "nergens blijkt, dat dit gevaar (de aantasting van de eenheid) in de gemeente radicaal buitengesloten is en blijven zal" (a.w., 44). Ook die kontinuiteit van dic Kerk word nie geteken ,in een sfeer van statische continuïteit zonder spanning en gevaar" (a.w., 211). „Geen enkele continuïteitsbeschouwing is dan ook legitiem, waarin de kerk niet meer tot de orde zou geroepen kunnen worden, omdat ze "definitieve" heilswerkelijkheid zou zijn" (a.w., 223).

"In deze onderscheiding tussen individuele gelovigen en de kerk, als geheel' staan we voor een nog nooit doorzichtig geworden constructie, omdat niet duidelijk valt te maken, hoe de kerk geissoleerd kan worden van de individuele gelovigen als „congregatio fidelium", als een ándere werkelijkheid, waarover ándere dingen kunnen worden gezegd", Berkouwer: De Kerk, a.w., p. 216; vgl. 217-221, 232. Dieselfde saak bring hy ook ter sprake in Gereformeerd Weekblad, 4 September, jg. 26, no. 9 e.v. In sy boek bring Berkouwer hierdie probleem ook in 'n ander verband ter sprake (i.v.m. die (on-)verliesbaarheid van die genade): „Opvallend is daarbij nu echter, dat Rome dit alles zeer bewust „individueel” heeft verstaan en het ecclesiologisch van geen betekenis achtte. Ten aanzien van de individuele gelovigen was er geen zekerheid t.a.v. de perseverantia sanctorum, maar geheel ánders stond het ten aanzien van de perseverantia ecclesiae". a.w., p. 212. Is die standpunt van die Reformasie nie dalk presies die omgekeerde nie? En is dit nie 'n valse, en daarom onvrugbare dilemmatiek nie?

21 Küng: a.w., p. 117.

22 Idem, p. 152 ; so op $358,481$.

23 Vgl. Küng: a.w., 393-394 en Berkouwer: a.w., 223.

24 Berkouwer verwys hier na Bavinck (G.D. IV, 308-309), wat van die onfeilbaarheid van die kerk gesè het dat dit "gaarne" deur die Protestante erken word, De Kerk, a.w., 25, 215. Ook Küng verwys na die „infallibiliteit van die kerk" as iets wat op die Skrif gebaseer is „en ook door de reformatoren niet bestreden werd", a.w., 393.

25 „Allereerst is het verstaan ((van de Bijbel)) dus iets dat aan heel de kerk toekomt, en daarom ook eerst bij heel de kerk veilig is. Dat heeft alvast oecumenische betekenis. Wij kunnen niet als kerkgroepering op eigen houtje gaan opereren met de waarheid", H. M. Kuitert: Verstaat gij wat gij leest?, J. H. Kok N.V., Kampen, 1968 (3), p. 67, so p. 80. Vgl. ook Klare Wijn. Rekenschap over geschiedenis, geheim en gezag van de Bijbel, Bockencentrum N.V., 's-Gravenhage, 1967, 228-233. Hierdie motief 
speel ook by Berkouwer 'n belangrike rol, vgl. De Kerk, a.w., 145, passim.

26 „Met verontrusting willen we slechts constateren dat de christenheid in zoveel, elkaar bestrijdende kerkgenootschappen is verdeeld dat men of aan de duidelikheid van de Schrifte moet twijfelen of aan het bestaansrecht van de vele kerken", $H$. M. Kuitert, idem, p. 63; vgl. 67, 82.

27 Polman: N.G.B. III, a.w., p. 231: „Wie de tegenstelling ware en valse Kerk vervangt door of verklaart in de zin van de onderscheiding meer of minder zuivere Kerken heeft de historische betekenis van de woorden der Belijdenis losgelaten en schrijft haar een andere mening toe dan zij bedoelt". Ook prof. S. P. van der Walt, al spreek hy van „gradasie van suiwerheid", wil nie daarvan weet dat "die onderskeid van meer en minder suiwere kerke... die belydenis van ware en valse kerke (kan) vervang nie”. Sy konklusie is „dat ook die mins suiwere kerk nog tot die ware kerk behoort", art. "Die Kerk en die Kerke" in Bulletin van die Suid-Afrikaanse Vereniging vir die bevordering van Christelike Wetenskap, April 1969, no. 18, p. 45.

28 Ten opsigte van Rom, $16: 17$ verwys $H$. N. Ridderbos na dwaalleraars "welke de gemeente verciclen", Aan de Romeinen, J. H. Kok N.V., Kampen, 1959, p. 348; (my kursivering, v.W.); eweneens W. D. Jonker: Die Brief aan die Romeine, N.G. herk-Uitgewers, Kaapstad, 1967, p. 203.

Van die „sommige mense” in Gal. 1 : 7 se Ridderbos: „They apparently constituted a group of persons who, from the outside, and also probably under alien influence, resisted Paul's preaching", The Epistle of Paul to the Churches of Galatia, Marshall, Morgan \& Scott, Edinburgh/London, 1961, p. 49. Die Judaiste het egter binnekerklik geopereer, vgl. idem, p. 47. In 2 Thess. 3 : 14 gaan dit oor 'n persoon wat ,,aan ons woord in (hierdie) brief nie gehoorsaam is nie". Ook in 1 Tim. $6: 8-9$ gaan dit oor 'n intrakerklike situasie, vgl. H. Ridderbos: De Pastorale Brieven, J. H. Kok N.V., Kampen, 1967, p. 150-151. T.o.v. Titus $3: 10-11$ : „Bedoeld zullen zijn zij, die zich onder de invloed van de dwaalleer laten brengen en daarmee de eenheid van de gemeente verstoren”. „Paulus spreekt hier dus niet van de dwaalleraars, maar van de afzonderlijke gemeentelid", Ridderbos: De Pastorale Brieven, a.w., p. 298 (my kursivering, v.W.); vgl. „de afwijkende broeder", idem. Ook in 2 Joh. 9-11 gaan dit uitdruklik oor iemand (en nie 'n gemeente nie) wat „nie bely dat Jesus Christus in die vlees gekom het nie"' (vs. 7).

29 „Ook de gemeenten, aan welke Paulus zijn brieven schrijft, of tot welke Christus Zelf Zich richt, blijken verre van volmaakt. Er zijn gebreken aanwijsbaar in sacramentsbediening ( 1 Cor. $11: 17-34$ ); in de Evangelieprediking (Gal. $1: 6,7 ; 3: 1$; Openb. $2: 14,15,20$ ); in de tuchthandhaving (Rom. $16: 17 ; 1$ Cor. $5: 1-5,2$ Cor. $12: 20$, 12, Tit. 1 : 10-14; Openb. 2 : 16, 20)", Praamsma in Het Dogma der Kerk, a.w., p. 507; „Dat echter niet bij gelegenheid van ieder gebrek of iedere tweedracht omtrent ceremoniën of bestuur, ja zelfs niet omtrent sommige leerstellige punten de vereeniging dadelijk moet worden opgeheven, leeren de voorbeelden der kerk van Corinthe en Galatië; en aan het gezonder deel heeft de apostel dit ook nie te raad gegeven", Voetius, a.w., p. 109-110, vgl. ook p. 88.

30 Vgl. art. In die Skriflig, Aug./Sept. 1968, jg. 2, no. 7, p. 23; vgl. ook Calvyn: Institusie, IV, 13, 14, vir sy kritiek teen benaminge soos Benediktyne, 
Franciskane en Dominikane. Calvyn het ook die term „Calvinisme” verwerp, vgl. V. E. d'Assonville in Die Goue Kanclelaur, 1970, p. 70. (Daar word selfs al beweer dat ,die Calvinisme 'n praktiese en dinamiese godsdiens is ..."(!), ds. J. N. Wolmarans in Hervornde Teologiese Studies, jg. 25, afd. 3 en 4 , p. 191).

312 Kor. 6 : 14-18: atroros: „hier niet afgevallenen, maar heidenen”, F. W. Grosheide: De Tweede Brief aan de Kerk te Korinthe, J. H. Kok N.V., Kampen, 1959 (2), p. 187. Vgl. „heulen met de wereld”, idem (my kursivering). Vs. 16: $\varepsilon \delta \omega \lambda \alpha$ is afgode/afgodsbeelde. Openb. $18: 4$ : Weliswaar dink Greijdanus nog hier aan die pousdom, De Openbaring des Heren aan Johannes, J. H. Kok N.V., Kampen, 1965 (4), p. 251-252 (by 17 : $3-5)$. Dit is 'n groot vraag of hierdie eksegese (nog) verantwoord is. Vgl., as enkele voorbeeld, S. C. W. Duvenage: Voor Sy Troon en hier benede, Pro Rege-Pers Bpk., Potchefstroom, 1960: „Romeinse ryk”, „internasionale organisasies", „antichristelike wêreldmag" (p. 185).

31a Vgl. T. van der Walt: „Die Nieu-Testamentiese kerk staan nog voor die droewige geskiedenis van kerkskeuring - ons daaragter. Daarom ook bied die Nuwe Testament geen direkte gegewens om tot die herstel van die eenheid te kom nie. Tog bied dit duidelik fundamentele riglyne...", in Handelinge van die Sinodale Verg. van die Geref. Kerk in S.A., 1967, Potchefstroom, p. 391; ook J. H. Roberts: Die Opbou van die Kerk volgens die Efese-brief, Groningen, 1963, p. 184: „Vasgehou moet word aan die pre-supposisie van die ongeskeurde gemeente vanwaar uit al sy ((Paulus se)) uitsprake gedoen is".

32 Vgl. H. Ridderbos: Paulus. Ontwerp van zijn Theologie, J. H. Kok N.V., Kampen, 1966, p. 463-474, veral 473: "In die zin kan men dus zeggen, dat het avondmaal grondslag én criterium is voor de eenheid der gemeente als het nieuwe volk van God". Sonder om 'n pleidooi vir die sg. „oop Nagmaal" te voer, moet mi. tog genoem word dat die (in 1964) gewysigde artikel 61 van die Kerkorde van die Geref. Kerk in S.A., wat bepaal dat toegang tot die Heilige Nagmaal verleen kan word aan „diegene wat uit ander kerke (van dieselfde kerkverband) kom", 'n versmalling is van die visie van Calvyn en van die Heidelbergse Kategismus (antw. 81), asook - hoogs waarskynlik - in stryd met die Kerkorde self, aangesien in artikel 9 die begrip "ander kerke" duidelik betrekking het op ander kerkgroepe.

33 „er moeten $\alpha \iota p e \sigma \varepsilon \iota s$ zijn en die zijn er niet, terwijl er wel $\sigma \chi \iota \sigma \mu \alpha \tau \alpha$ zijn,

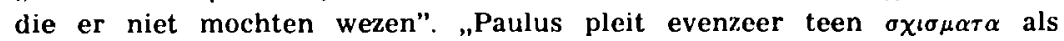
tegen een eenvormigheid, die het gevolg van onverschilligheid kan zijn. Er moet beweging in de gemeente zijn, die zich uit in de bespreking van allerlei vraagstukken, maar niet in het uit elkaar gaan", F. W. Grosheide: De Eerste Brief aan de Kerk te Korinthe, J. H. Kok N.V., Kampen, 1957 (2), p. 304. Vgl. Berkouwer: De Kerk, a.w., p. 36.

34 Bedoel word die Marcionistiese skeuring. "De voorstelling, dat er in de eerste eeuwen één grote ongedeelde kerk was, is dus onjuist". Hierdie kerkgroep het in die 5e eeu verdwyn, Berkhof: Geschiedenis der Kerk, a.w., p. 36 .

Küng: a.w., p. 355.

I. A. M. Fiolet: De Tweede Reformatie, Lemniscaat, Rotterdam, 1969, p. 68. 
37 H. Bavinck: De Katholiciteit van Christendom en Kerk, J. H. Kok N.V., Kampen, 1968 (oorspr. 1888), p. 38.

38 Polman: N.G.B. III, a.w., p. 292. Vir 'n kort skets t.o.v. die kerkhistoriese afsplitsingsproses in Nederland, vgl. J. Plomp in Geref. Weekblad, 14 Julie 1967, p. 10.

39 Vgl. Harvey Cox: De Stad van de Mens, Ambo N.V., Utrecht (dr. 8), (oorspr. 1965/66), p. 123-186 en 245-266.

40 Fiolet: a.w., p. 102. Vgl. titels soos „Sterwende Christendom?" (J. A. Heyns) en „Het die Christendom gefaal?" (H. du Plessis).

41 Vgl. Krispunte, jg. 4, no. 4, p. 2-3. Ons verwys slegs na die volgende „Uit Johannes 17 blijkt tevens hoe zinloos het is de waarheid tegen de eenheid of de eenheid tegen de waarheid uit te spelen (wat is ,het belangrijkste"?) nu het om deze eenheid gaat, vgl. Joh. $17: 13$ (het Woord); 17 : 19 (de waarheid); de $\operatorname{Naam}(17: 26)$ ", Berkouwer: De Kerk, a.w., p. 56, noot 135; vgl. ook sy Het Licht der Wereld. Het Evangelie van Johannes, J. H. Kok N.V., Kampen, 1960, p. 139: „Er is dan ook geen sprake van een spanning tussen „eenheid" en „waarheid" en men moet deze twee niet tegen elkaar uitspelen. Men mag niet zeggen: het gaan érst om de eenheid en dan pas om de waarheid en men mag ók niet zeggen: het gaat éérst om de waarheid en dan pas om de eenheid". Ter plaatse, $B$. Duvenage: „Dit is 'n verkeerde dilemma om die eenheid teen die waarheid of die waarheid teen die eenheid uit te speel. Daar kan geen sprake van kerklike eenheid sonder ooreenstemming in die waarheid wees nie, maar net so kan geen kerk met die pretensie kom dat hy die waarheid besit as hy hom nie naarstig beywer vir die eenheid van die kerk nie" (p. 5); dit sou nie verkeerd wees nie „as die Gereformeerde Kerk in Suid-Afrika ook 'n gesprek met die Roomse Kerk probeer voer nie om so die waarheid van die Skrif ook daar te laat geld nie" (p. 6), Ware en Valse Ekumenisiteit, Studiestuk no. 6 van die Instituut vir die Bevordering van Calvinisme (s.j.).

42 Vgl. Praamsma in Het Dogma der Kerk, a.w., p. 510 en K. Dijk: Korte Dogmatiek, a.w., p. 271.

43 Vgl. S. P. van der Walt se drie maal herhaalde sin dat "die wese van die kerk lê in sy eenheid", a.a., p. 38, 44, 46.

44 „Die ekumeniese roeping van die kerk bestaan derhalwe nie daarin om tot stand te bring wat nog nie bestaan nie, maar om tot uitdrukking te bring wat die kerk is en wat ons omtrent die kerk bely", W. J. Snyman: Die kerk en sy ekumeniese roeping volgens die Nuwe Testament, in Handelinge van die Sinodale Verg. van die Geref. Kerk in S.A., Potchefstroom, 1967, p. 379; Küng: De Kerk, a.w., p. 329: „De eenheid van de kerk is dus niet louter doel maar ook reeds wortel van het absoluut noodzakelijke streven naar de eenheid van de kerk". Dit is frappant om op te merk hoedat hierdie twee genoemde gereformeerde en roomskatolieke teoloë ooreenstem t.o.v. die N.T. kerkbegrip!

44a So Veenhof t.o.v. Calvyn: a.w., p. 112-119.

45 "It must be constantly kept in mind, that the sense and content of a dogma are to be historically understood in the first instance as in contrast with some particular doctrinal view", R. Seeberg: Textbook, a.w., I, p. 21. Ons moet tewens onthou dat "uit de kerk weggaan betekent verloochening 
van God en Christus", Calvyn; Institusie, IV, 1, 10.

46 Vgl.: „De opsteller van onze belijdenis Guido de Bres erkende de Lutherse kerken als ware kerken van Jezus Christus en poogde met hen tot vereniging te komen. Hij handelde daarmee geheel in het voetspoor van Calvijn, die de Lutherse kerk cen ware kerk van Christus achtte", Praamsma in Het Dogma der Kerk, a.w., p. 512 (m.v.n. P. J. Richel: Het Kerkbegrip van Calvijn, 1942, 134-138).

47 'n Opvallende diskrepansie tussen die Heidelbergse Kategismus (waar ekskommunikasie en afsnyding saamval) en die Dordtse Kerkorde (waar ná ekskommunikasie nog drie trappe volg op weg na 'n afsnyding). Afhouding van die Nagmaal is reeds by Augustinus te vind, Seeberg: Textbook, a.w., I, p. 364 .

47a Tereg skryf J. van den Berg in Geref. Theologisch Tijdschrift, Aug. 1970, jg. 70, no. 3, p. 174: „Daar zijn situaties, waarin de verwevenheid van schuld en onschuld aan beide zijden zó complex is, dat elk pogen om achteraf de draden te ontwarren tot nog groter verwarring en vervreemding leidt. We kunnen het verleden niet overdoen..." Vgl. ook Kruispunte, Mei 1967, jg. 3, no. 3, p. 5-7.

48 Küng: a.w., p. 338. So ook Barth: „Konversionen” von uns hinüber zur römisch-katholischen Kirche, oder umgekehrt: von dort herüber zu einer unserer Kirche habe als solche keinen Sinn (peccatur intra muros et extra!). Sie können einen Sinn nur haben, wo sie die gewissensmäszig notwendige Gestalt von „Konversion” - nicht zu ciner anderen Kirche, sondern zu Jesus Christus, dem Herrn der einen, heiligen, katholischen und apostolischen Kirche sind. Grundsätzlich kann es hüben und drüben nur darum gehen, dasz ein jeder sich an seinem Ort in seiner Kirche zum Glauben an den einen Herrn und in seinen Dienst rufen lasse", Ad Limina Apostolorum, 1967, p. 17-18, aangehaal in De Oude Barth, zoals wij hem hoorden in colleges en gesprekken (A. Dekker en G. Puchinger), J. H. Kok N.V., Kampen, 1969, p. 75. Op weg na die een Kerk is vele daarom bereid om die gestalte van die „eie kerk” prys te gee, omdat kerk-wees en 'n bepaalde gestálte van kerk-wees nie identiek is nie. (Hierdie motief het skerp na vore gekom by dic sitting van die Wêreldraad van Kerke te Evanston, 1954). Volten skryf: „Maar er is geen oecumenische geladenheid - in geen enkele kerk -, er wordt geen ernst gemaakt met het gebed van Christus om de eenheid der kerk, wanneer men niet bereid is, om de vorm van zijn eigen kerk op te heffen", Rondom het Belijden der Kerk, a.w., p. 161. Kuitert stem hiermee saam: „Voor mij zal kerk niet helemaal hetzelfde zijn als voor $\mathrm{u}$ ((nl. H. N. Ridderbos)). Daarom kijk ik wat vrolijker tegen de uitholling en het functicverlies van het huidige kerkelijke instituut aan. Dat overleeft de gemeente dic Jezus zich bijeen vergadert wel. Het is misschien zelfs reuze nuttig dat geen steen van het oude model op de andere blijft staan ... Over het voortbestaan van Gods volk ben ik dus vol vertrouwen", in Geref. Weekblad, 13 Maart 1970, jg. 25, no. 37, p. 243. Ook die ChristelikGereformeerde ds. J. H. Velema hanteer hierdie onderskeiding: „Er staan nergens in de Bijbel bepaalde beloften voor een kerkelijk instituut... we hebben geen garantie dat een bepaalde kerk tot op de jongste dag zal blijven bestaan. Ook de Chr. Geref. Kerk niet”. „Het is onmogelijk 
Gods werk vast te pinnen aan een kerk... Als we Gods werk en ,onze' kerk gaan identificeren, plegen we afgoderij met de kerk; vergrijpen wij ons aan Gods werk en lopen gevaar geestelijk hoogmoedig te worden", in Kerk en Pers '68, Bosch en Keuning N.V., Baarn, 1969, p. 7-8 (oorspr. in De Wekker, 17 Mei 1968). Totius verwys na Roomse en Oosters-Ortodokse roepstemme om „oor te kom", en vra: "Is dit ook onder Protestante nie soms die gesindheid nie: „Kom oor na my instituut en ... ons is een"?, V.W. VII, a.w., p. 509. Vgl. die Openlike Verklaring by vergaderinge van die Geref. Kerk in S.A.: „Almal wat met ons dieselfde dierbare geloof verkry het deur die genade van die Heilige Gees en dit met ons wens te bely en te betrag nodig ons hartlik uit tot ons kerklike gemeenskap" (my kursivering, v.W.), Kerkorde van die Geref. Kerk in S.A., Potchefstroom, 1968, p. 90).

48a Vgl. die besluit van die Algemene Sinode van die Geref. Kerk, 1970: „Dat, terwyl die sinodale deputate besig is om in samespreking met ander kerke by vernuwing onder oë te sien wat die Gereformeerde en daardie kerke uit mekaar hou, geen offisiële samesprekings intussen op plaaslike vlak daaroor sal plaasvind nie", volgens Die Kerkblad, 20 Mei 1970, p. 3. Dit is myns insiens ' $n$ illusie om te dink dat Kerklike eenheid bereik sal word wanneer die Sinodes van die Kerkgroepe ooreenstemming bereik het, terwyl daar niks in die onderskeie plaaslike kerke bespreek en gedoen is nie. Ons het hier te doen met 'n sinodokratiese vereniging van die ekumeniese roeping van die kerk. Bowendien word die woord "kerk" in genoemde besluit in onbybelse sin gebruik.

49 G. Th. Rothuizen meen dat Bonhoeffer die dogmatiese verskille binne die Protestantisme groter geag het as dié tussen Rome en Reformasie: „De weg van de ecumene leidt midden door een confessionaal relativisme, waaraan het protestantisme zo rijk is en het confessionaal absolutisme, waarin de katholieke kerk uitmunt", Aristocratisch Christendom. Over Dietrich Bonhoeffer, J. H. Kok N.V., Kampen, 1969, p. 176. „Zo loopt ((vir Bonhoeffer)) de weg midden tussen de zuivere kerk (die nooit bereikt wordt) en de quasi kerk (de volkskerk) dór of: zij loopt midden tussen de scylla van een orthodoxie, die geen idee heeft dat de belijdenis op velerlei wijze gehandhaaf kan worden en de charybdis van de belijdenisloosheid door", idem, p. 192. Bonhoeffer self was van oordeel dat „de tegenstelling tussen lutheranen en hervormden niet meer reëel zijn; dit geldt goeddeels ook voor de tegenstellingen met de katholieken", Verzet en Overgave, W. ten Have N.V., Amsterdam, 1968, p. 148. H. Zahrnt wys daarop dat vir Brunner, „de veelheid van elkaar beconcurrerende kerken weliswaar een steen des aanstoots is, maar de veelvormigheid van de Christus-gemeenschap is een noodzakelijkheid", Wachtend op God. De Duitse protestantse theologie in de twintigste eeuw, Aubo N.V., Utrecht, 1967, p. 83-84.

50 Barth verwys bv. na die „nuwe teoloë" (o.a. Sölle) as „Plattfusteoloë" (die Baselse dialek vir 'n lekband). „Ze rekenen niet met de Heilige Geest en daarom doen ze alsof ze zelf de wereld moeten dragen", in De Oude Barth, a.w., p. 147. Dr. L. F. Schulze verwys na Barth en Berkouwer as "konserwatiewe teoloë" in verband met die God-is-dood-teoloë, in Kruispunte, Des. 1968, no. 5, jg. 4, p. 13. (Athanasius het bv. die homoiousiane 
„broeders" genoem!, Secberg: T'extbook, a.w., I, 226). I.v.m. die „verskeidenheid" merk J. C. Groot op: „Niet alle verschillen, die tussen de kerken in hun verdeeldheid bestaan, zullen hoeven te verdwijnen. Eenheid is immers geen eenvormigheid. Zij kan, ja zij moet gepaard gaan met een legitieme pluriformiteit", art. „Van eenvormigheid naar pluriformiteit” in Uit tweë̈n één. Tussentijdse balans van het gesprek Rome-Reformatie, Rotterdam, 1966, p. 253-269.

51 Die Chiliasme is reeds te vind by Justinus Martyr, Irenaenus, Cyprianus en Tertullianus. Dit is egter skerp bestry deur Augustinus, vgl. Het Dogma der Kerk, a.w., p. 578.

52 Küng, a.w., p. 295.

53 Idem, p. 358.

54 Polman: N.G.B. III, a.w., p. 339. Volgens Nijenhuis was Calvyn anti-konfessionalisties, Calvinus, a.w., p. 298-299.

55 J. H. Kok N.V., Kampen, 1962.

56 A.w., p. 207. Calvyn het ook tussen fundamentele en nie-fundamentele leerstukke onderskei, Nijenhuis: Calvinus, a.w., p. 281-283 (Inst. IV, 1, 12; IV, 2, 1).

57 Idem, p. 209. „Niet ieder volk kan op dezelfde wijze zich uitdrukken in belijdenis, in liturgie. En ook met de wijze van kerkregering kan men niet omgaan als met een passepartout", H. N. Ridderbos: „Kerk en Volk" in 'n Lig vir die Volke, Pro Rege-Pers Bpk., Potchefstroom, 1969, p. 38. Berkouwer onderstreep die probleem-situasie: „In de analyse van de haeresie komen we thans in aanraking met historisch-kerkelijke ontwikkelingen, met verschillende inzichten in de waarheid Gods, met confessionele tegenstellingen. Daarin heeft wel niemand - geen enkele kerk de moed om in de kerkelijke verdeeldheid de radicaliteit van Paulus' afweer tegen de haeresie (anathema!) zonder meer te transponeren in de huidige verdeeldheid tussen kerken en confessies en ten aanzien van „de anderen" Paulus' woorden over de schipbreuk, de afval en de breuk met Christus waarschuwend en in de laatste ernst over te nemen", De Kerk, a.w., p. 143. Vgl. ook S. du Toit: Bybel-Skepping-Ewolusie, Voortrekkerpers 19682 , p. $56-57$.

58 In Geref. Weekblad, 3 Nov. 1967, p. 114. Vgl. ook Berkouwer se reeks artikels "Over de identiteit der kerk" in Geref. Weekblad, 3 April 1970 e.v. Ons moet m.i. goed onderskei tussen fórmele en máteriële reduksie van die belydenis.

59 In Geref. Weekblad, 27 Junie 1969, p. 362. Ook in sy verontrusting en Verantwoordelijkheid (J. H. Kok N.V., Kampen, 1969) bring Berkouwer die saak ter sprake: „En het is duidelijk, dat de kerk in alle bezinning over de belijdenis altijd weer op deze centraliteit en radicaliteit wordt teruggeworpen. We komen hier m.i. in aanraking met het meest centrale punt van alle belijdenis-problematiek m.n. ten aanzien van de binding..." (p. 144). Hy verwys ook na Kuyper se ideaal vir 'n Belydenis: ,een belijdenis bevatte niets anders dan datgene, waarvan men voor God betuigen kan, dat het afdoet ter zaligheid" (Confidentie, 1873, p. 97), idem, p. 143, noot 47. Vgl. sy De Kerk, a.w., p. 188, insake „de eigenlijke vráá". Ridderbos het hom ook inderdaad met die probleem besig gehou: "Intussen blijft dan wel het probleem van de kerkelijke eenheid, als een 
organisatorische kwestie. Kunnen Lutheranen en Calvinisten, ieder met behoud van eigen confessie, éen kerk vormen? Het zou moeten kunnen. Maar men kan er weer uit leren, dat hoe uitgebreider en specialer een belijdenis is en gezien de historie soms ook moest zijn, zij de eenheid der kerk mécr in de weg staat. Ook onze gereformeerde belijdenis, hoewel men er niets uit kan schrappen, zonder haar te verminken, is voor de eenheid van de kerk te uitgebreid en te theologisch", in Geref. Weekblad, 9 Sept. 1966, p. 50. A. J. Venter wil die oplossing nie in reduksie soek nie, „maar eerder in 'n verdere ontvouing op grondslag van en met eerbiediging van die bestaande belydenis", Kerk en Belydenis, Potchefstroom, s.j., p. 59 .

60 Acts and Reports of the Reformed Ecumenical Synod 1968, Amsterdam, p. 215. Vgl. Bavinck: „De leer van Christus is niet het uitgangspunt, maar wel het middelpunt der gansche dogmatiek... In haar als het hart der dogmatiek klopt heel het religieus-ethische leven der Christenheid, Gereformeerde Dogmatiek, III, (4), p. 254. Totaal anders by M. J. Booyens: Die Kerkblad, 20 Aug. 1969, p. 14: „Ek weet maar al te goed dat my kerk en my huis alleen kan lewe as die Afrikaanse volk lewe". 'n Vlotte identifikasie van die gekonsentreerde N.T. belydenis, nl. dat Jesus die Messias en Seun van God is, met die drie formuliere van eenheid, kan m.i. grootliks bevraagteken word, vgl. L. Floor en W. J. Snyman in Die Koninkryk van God, a.w., p. 36-37. Die Kerk het sestien eeue bestaan sonder diê uitgebreide belydenis, maar dit kan nie een sekond bly staan sonder die Messiaanse belydenis nie. Dit verdien daarom aanbeveling om by die aflegging van geloofsbelydenis hierdie radikale vraag prominent voorop te plaas - as belydenisvraag - en dat daarná volledige instemming betuig word met die waarheid dat die Bybel Gods Woord is en die Bely. denisskrifte daarop gebaseer is ens. In hierdie verband - in die lig van Matt. $16: 16$ en 1 Kor. $12: 3-$ is die woorde van art. 61 Kerkorde, naamlik dat belydenis van die "Gereformeerde Godsdiens" gedoen word, aanvegbaar (my kursivering, v.W.). In hierdie verband word dikwels kritiek gelewer op die gekonsentreerde „basisformule" van die Wereldraad van Kerke. W. J. Snyman oordeel dat „kritiek teen die basisformule van die Wêreldraad van Kerke is ter sake wanneer die basisformule bedoel is as basis van kerklike eenheid, maar nie as dit gesien word as uitgangspunt tot herstel van die eenheid nie", Handelinge van die Sinodale Verg. van die Geref. Kerk in S.A. 1967, Potchefstroom, p. 384. So ook Snyman in Agenda/Reports RES 1968, Amsterdam, p. 171: „On the other hand I would have no objection to an unqualified acceptance of the Basis with its addition as a starting point of ecumenical discussions...". Vgl. ook Totius se opmerking oor die - nog onuitgebreide - basisformule: „Hierdie getuienis is treffend en laat nadink", V.W. VIII, a.w., p. 16. Kritiek op die basisformule van die Wêreldráad word m.i. fundamenteel beheers deur die vraag of dit gesien word as „eindpunt" dan wel as „vertrekpunt" van kerklike eenheid.

60a Mens dink in hierdie verband ook daaraan dat twee van die mooiste belydenisskrifte, naamlik die Tweede Helvitiese Konfessie (1566) en die Westminsterse Konfessie (1647), nie deur die Geref. Kerk in S.A. aanvaar is nie (vgl. De Klerk: Geref. Simboliek, a.w., pp. 63, 50, 84), al word dit 
wel in ekumeniese verband gedoen - maar dan ook saam met die Galliese Konfessie en die 39 Artikels (vgl. Basisformule van die G.E.S.).

61 Vgl. S. J. van der Walt: "Selfs in ons eie Belydenis is die koninkryksgedagte nie breed uitgewerk nie", in Die Koninkryk van God, a.w., p. 151; vgl. in dieselfde boek H. Dijkstra, p. 185-214; ook W. D. Jonker: Mistieke Liggaam en Kerk in die Nuwe Rooms-Katolieke Teologie, J. H. Kok N.V., Kampen, 1955, stelling 19: „Dit moet betreur word dat in die eskatologiese uitsprake van artikel 37 van die Nederlandse Geloofsbelydenis nie meer tot uitdrukking kom van die kosmiese allure van die eskatologiese herstelling van die Ryk en die voldrae visie van 1 Kor. 15 : 24-28 nie"; en sy Aandag vir die Kerk, Potchefstroom, s.j., p. 57. Vgl. die uitdagende uitspraak van C. Augustijn: Kerk en Belijdenis, J. H. Kok N.V., Kampen, 1969, p. 70: „Eén uitspraak van die Gereformeerde Kerken, waarin bepaald wordt dat de overheid, de kerken en haar leden een bepaald percentage van hun inkomsten behoren te besteden aan ontwikkelingshulp, is vandag meer waard dan welke binding aan een oude of een nieuwe belijdenis"; en in die verband $\mathrm{J}$. ' $Г$. Bakker: „Om hetzelfde te zeggen moet het vandaag ánders gezegd worden dan gisteren, anders praten we op een bepaald moment niet slechts voor een saal die leeggelopen is, maar dan zéggen we ook niet meer hetzelfde als gisteren", in Geref. Weekblad, 29 Mei 1970, jg. 25, no. 47, p. 321. Die vraag word dikwels gestel of die na-reformatoriese teologie nie ontaard het in 'n "pessimistiese teologie" waarin daar geen sprake meer kan wees van 'n ,triomf van die genade" en van 'n oorwinnende Koninkryk nie, en waarin 'n fatalistiese hamartologie 'n dominerende rol speel. Opvallend, in hierdie verband, is die uitlatinge van twee teoloë: Die een oordeel dat dit "kwart ór middernag" is (Tjaart van der Walt in „Die Koninkryk van God, a.w., p. 106) en die ander dat dit „vyf minute voor twaalf" is (J. W. Jansen van Ryssen: Die Messias uit die Aarde. Oor die Antichris, Pro Rege-Pers Bpk., Potchefstroom, 1956 (2), p. 13).

Volgens R. H. Bremmer was Bavinck in sy tyd reeds daarvan oortuig dat die tyd aangebreek het „op bepaalde punten van de belijdenis te komen tot nadere formulering en uitwerking", Herman Bavinck als Dogmaticus, J. H. Kok N.V., Kampen, 1961, p. 384, vgl. 124.

62 Vgl. die belangrike studie van G. P. L. van der Linde: Die Grondbeginsels van die Presbiteriale Kerkregeringstelsel, Pro Rege-Pers Bpk., Potchefstroom, 1965.

63 R. Boon: Apostolisch Ambt en Reformatie. Primair Probleem der Oecumene, Nijkerk, Callenbach, 1965, p. 201-202.

64 In Geref. Theologisch Tijdschrift, Aug. 1966, p. 138.

65 Bavinck kies vir 'n sinodale kerkregering, maar noem tog - i.v.m. die Independentisme - dat ,de gronden, die tegen de synodale kerkregering kunnen worden ingebracht, ook inderdaad niet van gewicht zijn ontbloot", Geref. Dogm. IV (4), p. 414.

66 In Geref. Weekblad, rondom 1967; tans ongelukkig nie verifieerbaar nie. Vgl. ook sy Beginselen van reformatorisch kerkrecht, J. H. Kok N.V., Kampen, 1967. Ook in sy proefskrif: De kerkelijke tucht bij Calvijn, J. H. Kok N.V., Kampen, 1970 - wat ek nog nie onder oë gehad het nie -, is die volgende stelling verdedig: „Calvijns positie in de kerk van Geneve heeft een in hoge mate bisschoppelijk karakter gedragen" (iv), aangehaal 
in Geref. Theologisch Tijdschrift, Aug. 1970, jg. 70, no. 3, p. 174. Nijenhuis wys daarop dat Calvyn nie veel beswaar had teen die episkopaat as sodanig nie, Calvinus, a.w., pp. 200-219, 252, 304.

67 In Geref. Weekblad, 17 Nov. 1967, p. 123. Ook H. N. Ridderbos is van oordeel dat die presbiteriaal-sinodale kerkregeringstelsel duidelike gebreke toon, vgl. Geref. Weekblad, 13 Okt. 1967, p. 90. Vgl. A. J. Venter: „Al te snel en gemaklik word dikwels in ons kringe die stelling gemaak dat die Skrif slegs een vorm van kerkregering ken, nl. die presbiteriaal-sinodale stelsel. In die jongste tyd het gesaghebbendes vrywel eenstemmig tot die slotsom gekom dat dit in die lig van 'n noukeurige Skrifondersoek nie steekhou nie", in Kruispunte, Des. 1968, jg. 4, no. 5, p. 3.

Aangesien „preshiters" in Titus $1: 5$ en „episkope" in Titus $1: 7$ as wisselterme en in identifikasionerende sin gebruik word, is daar - terminologies ten minste - geen verskil tussen „presbiteriaal” en „episkopaal” nie. Vgl. H. Ridderbos: Pastorale Brieven, a.w., p. 259: „Er wordt thans niet meer van oudsten, maar van opziener gesproken, overigens geheel in dezelfde zin..." (my kursivering, v.W.).

68 Volten: Rondom het Belijden der Kerk, a.w., p. 207. Vgl. die volgende uitspraak van A. A. van Ruler - vol innerlike spanning - ,Met het oog op de getalsverhoudingen in wereldverband wordt het voor mij een steeds drukkender vraag, of wij niet ter wille van die eenheid van Christus' kerk de presbyteriaal-synodale vorm van kerkregering moeten opgeven en de bisschop - met al zijn gezag, dus niet puur als ornament of historisch filtraat! - als teken van de eenheid moeten aanvaarden. Perzoonlijk ben ik er van overtuigd, dat de presbyteriaal-synodale vorm van kerkregering de meest zuivere, de meest katholieke en ook de meest nieuw-testamentische vorm is, die tot dusver bereikt is. Ik houdt het er zelfs voor, dat haar afschaffing ook de structuur van de religie zou raken. Toch meen ik, dat wij ernstig moeten overwegen, of wij er aan vast mogen houden, of wij niet op dit punt terwille van de eenheid de waarheid moeten prijsgeven", in Kerk en Theologie, 4 Okt. 1967, p. 329-330.

69 Küng, a.w., p. 207. Vgl. Constituties en Dekreten van het Tweede Vaticaans Oecumenisch Concilie, Amersfoort, 1967, p. 51-126, 141-160.

70 Agenda/Reports RES 1968, Amsterdam, a.w., p. 215.

71 Küng, a.w., p. 544: „Een hereniging van gescheiden christelijke kerken bij het huidige nog altijd centralistische romeinse systeem is voor alle tijden ondenkbaar". S. du Toit: „Dit is hierdie kerkreg ((kollegialisme)) wat ons vereniging in die toekoms nog die meeste in die weg sal staan", in Eeufees te Rustenburg, Potchefstroom, 1959, p. 151. In die sinodale besluit van die Geref. Kerk oor ekumeniese sake word ook telkens verwys na die "belydenis én kerkregering", vgl. Die Kerkblad, 13 Mei 1970. Van Ruler oordeel: „De oecumenische vraag is in de kern een kerkelijke vraag en de kerkelijke vraag is in de kern een institutaire vraag", in Kerk en Theologie, 4 Okt. 1967 , p. 331.

72 Vgl. Agenda/Reports RES 1968, a.w., p. 215.

73 By Volten, a.w., p. 197, noot 2. Calvyn was van mening "dat men zich door verschillen in liturgie en kerkorde niet mochten laten scheiden van elkander, indien men in de doctrina én was", Nijenhuis: Calvinus. a.w., p. 303 . 
Polman: N.G.B. III, a.w., p. 234.

75 Idem, p. 362. Vgl. Küng: a.w., p. 316: „Tot het wezen van de kerk behoort noch een uniforme liturgie, noch een uniforme kerkorde, noch een uniforme theologie".

76 In dieselfde Spore, Potchefstroom, 1964, p. 66.

77 Idem, p. 66 (allereers met die sendingsituasie voor oё). Vgl. W. J. de Klerk: Wending? Vernuwingsgesprekke oor die Gereformeerde Kerkpraktyk, Pro Rege-Pers Bpk., Potchefstroom, 1964, p. 51-81.

78 „Het grote gevaar van de kerk, over de gehele wereld, is inderdaad haar introversie", H. Berkhof: De Leer van de Heilige Geest, a.w., p. 42. Vgl. in die verband ook: J. C. Hoekendijk: De Kerk Binneste Buiten, W. ten Have N.V., Amsterdam, 1964.

79 Küng, a.w., p. 327. Vgl.: „Wij kunnen niet meer de weg van een kerkscheuring op, zodra wij sterke divergenties zien. Dat hebben we natuurlijk nooit gekund; wel gedaan, maar nooit kunnen of mogen doen. Wij zien dat vandag beter dan 20 jaar of 100 jaar geleden. Verbreking van de eenheid der kerk wordt wetmatig een repeterende breuk - ik hoef niets met naam en toenaam te noemen - d.w.z. het kwaad straft zichzelf. Tenslotte bij de kleinst ondeelbare veelvoud uitgekomen, is de Reformatie machteloos geworden, uitgespeeld voor God en de mensen, zoals menig kerkgenootschap vandaag als een dreigend lot boven het hoofd hangt. Wij moeten dus ophouden met elkaar te overtreffen in het stichten van de meest zuivere kerk...", H. M. Kuitert, in Geref. Theologisch Tijdschrift, Nov. 1966, jg. 66, no. 4, p. 215.

80 „Die drie Afrikaanse kerke - dit sê al genoeg: drie kerke, in plaas van één kerk. Dit moet een kerk word, want al drie het deel aan die een kerk waarvoor Christus gebid het", Tjaart van der Walt, in Almanak van die Geref. Kerk in S.A., 1965, Potchefstroom, p. 196. Vir dieselfde strewe vgl. L. F. Schulze in Bulletin S.A.V.B.C.W., Nov. 1968, no. 16, p. 245 (,ons tyd is ryp om weer die verlore eenheid te soek..."), F. J. Potgieter in Die Kerkbode, 8 Junie 1966, p. 747. (Genuanseerd: „Dit het tyd geword dat die behoudendes uit al drie kerkverbande toenadering tot mekaar soek) en Die Kerkbode, 28 Okt. 1970, p. 610; J. C. G. Kotze: Wie beset hierdie bedreigde huis?, Kosmo-uitg., Stellenbosch, 1964, p. 150; W. J. Snyman: Openbaringsgeskiedenis van die N.T., (Diktaat), Potchefstroom, 1967, p. 72: „Die gedeeldheid in die kerkgenootskappe soos ons dit ken, is iets wat nie so moet wees nie". (Anders as voorheen: „Daarom is daar plek vir meer kerke op een plek in verskillende kerkverband, in die verhouding: suiwerder-minder suiwer", art. oor "Die Kerk" in Die Kosbare Goud, Gereformeerde Geloofsleer, Nas. Pers Bpk., Kaapstad, 1942, p. 219).

Terwyl die N.G. Kerk rondskipper t.o.v. 'n konsekwente ekumenisme (die Geref. Ekumeniese Sinode van 1968 het op bepaalde punte veel skerper besluite oor die rassekwessie geneem as die Cottesloe-beraad van 1960), worstel die Herv. Kerk om te kom tot 'n ekumeniese engagement. A. D. Pont is dankbaar dat die Herv. Kerk ,sy bande met hierdie verderflike beweging ((Wereldraad van Kerke)) verbreek het en dat die invloed van die sogenaamde ekumeniese teologie in ons Kerk tot 'n nulpunt gedaal het" (Die Hervormer, Aug. 1968, p. 24); A. J. van Staden is van oortuiging "dat ons by hierdie ekumeniese liggaam ((Geref. Ekumeniese Sinode)) aansluiting moet soek" (Herv. Teologiese Studies, jg. 24, afl. 1, s.j., p. 65). 